UCRL-CR-146982

B512155

\title{
Geologic Repository Plan for Disposal of PU- Containing and other Radioactive Materials in Russia
}

L. Jardine and T.A. Gupalon

December 6, 2001

U.S. Department of Energy

Lawrence

Livermore

National

Laboratory 


\section{DISCLAIMER}

This document was prepared as an account of work sponsored by an agency of the United States Government. Neither the United States Government nor the University of California nor any of their employees, makes any warranty, express or implied, or assumes any legal liability or responsibility for the accuracy, completeness, or usefulness of any information, apparatus, product, or process disclosed, or represents that its use would not infringe privately owned rights. Reference herein to any specific commercial product, process, or service by trade name, trademark, manufacturer, or otherwise, does not necessarily constitute or imply its endorsement, recommendation, or favoring by the United States Government or the University of California. The views and opinions of authors expressed herein do not necessarily state or reflect those of the United States Government or the University of California, and shall not be used for advertising or product endorsement purposes.

This work was performed under the auspices of the U. S. Department of Energy by the University of California, Lawrence Livermore National Laboratory under Contract No. W-7405-Eng-48.

This report has been reproduced directly from the best available copy.

Available electronically at http://www.doe.gov/bridge

Available for a processing fee to U.S. Department of Energy

and its contractors in paper from

U.S. Department of Energy

Office of Scientific and Technical Information

P.O. Box 62

Oak Ridge, TN 37831-0062

Telephone: (865) 576-8401

Facsimile: (865) 576-5728

E-mail: reports@adonis.osti.gov

Available for the sale to the public from

U.S. Department of Commerce

National Technical Information Service

5285 Port Royal Road

Springfield, VA 22161

Telephone: (800) 553-6847

Facsimile: (703) 605-6900

E-mail: orders@ntis.fedworld.gov

Online ordering: http://www.ntis.gov/ordering.htm

OR

Lawrence Livermore National Laboratory

Technical Information Department's Digital Library

http://www.llnl.gov/tid/Library.html 
UCRL-XX-XXXXXX

\section{GEOLOGIC REPOSITORY PLAN FOR DISPOSAL OF PU- CONTAINING AND OTHER RADIOACTIVE MATERIALS IN RUSSIA}

Final Report, Material Support Agreement B512155 between the University of California and the All-Russian Research and Design Institute of Production Engineering (VNIPIPT)

L. J. Jardine, LLNL

T. A. Gupalo, VNIPIPT

December 6, 2001 


\section{DISCLAMMER}

This document was prepared as an account of work sponsored by an agency of the United States Government. Neither the United States Government nor the University of California nor any of their employees, makes any warranty, express or implied, or assumes any legal liability or responsibility for the accuracy, completeness, or usefulness of any information, apparatus, product, or process disclosed, or represents that its use would not infringe privately owned rights. Reference herein to any specific commercial product, process, or service by trade name, trademark, manufacturer, or otherwise, does not necessarily constitute or imply its endorsement, recommendation, or favoring by the United States Government or the University of California. The views and opinions of authors expressed herein do not necessarily state or reflect those of the United States Government or the University of California, and shall not be used for advertising or product endorsement purposes.

Work performed under the auspices of the U.S. Department of Energy by Lawrence Livermore National Laboratory under Contract W-7405-ENG-48. 


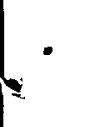

.

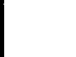

- 


\section{CONTENTS}

INTRODUCTION 1

CHAPTER 1. THE BASIC PROVISIONS 3

1.I Russian Approach to the Creation of Geological Repositories for Plutoniumcontaining Materials and Radioactive Waste.

1.1.1 ... Review and analysis of Russian Federation current laws and concepts on radioactive waste management

1.1.2 Design documentation and licensing procedures for design, construction, and operation of an $\mathrm{RW}$ geological repository

1.1.3 Requirements for creation of quality control programs of RW management ........................8

1.1.4 Management and organization of work in the RW geological repository project...................8

1.1.5 Russian Science and Technology Center Proposed for RW Disposal Technologies .............10

1.16 Basic legal acts and ruling documents ...............................................................................11

1.2 Engineering-Geologic Survey for Construction of the Site for Underground RW Isolation

CHAPTER 2. DESIGN SURVEY AND SCIENTIFIC RESEARCH IN THE

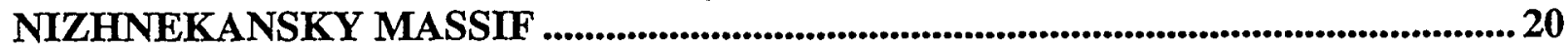

2.1 Investigation of Promising Sites at the Nizhnekansky Massif................................ 20

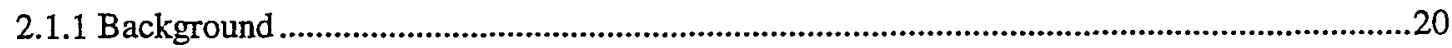

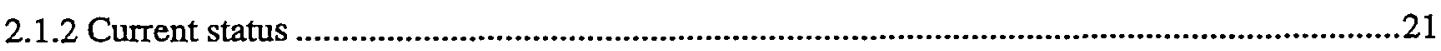

2.2.1 Survey and research work .....................................................................................................23

2.2.2 Development of DOI for construction of repository site and underground laboratory ...........24

2.3 Development of the Justification of Investment ................................................24

2.3.1 The engineering survey ....................................................................................................25

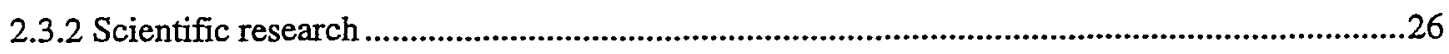

2.3.3 Design, ecological assessment, and expert review for JOI ..................................................27

2.4 Underground Laboratory .................................................................................. 27

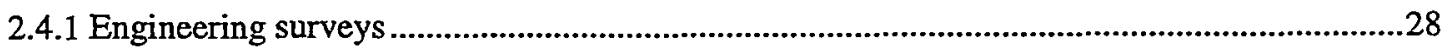

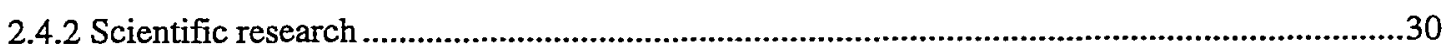

2.4.3 Working design for underground laboratory construction ....................................................30

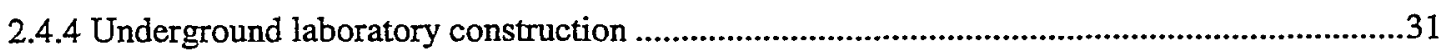

2.5.5 Scientific research and experimental work in the underground laboratory .............................31

2.5 Development of TEO for Construction of the RW Repository Site ..................... 32

2.5.1 Engineering surveys for TEO development .............................................................................33

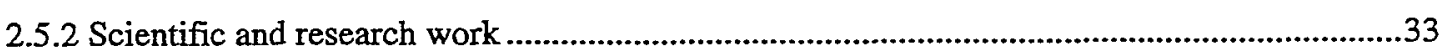

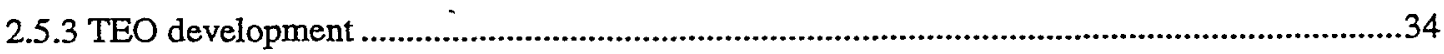

2.6 Development of Working Documentation for Repository Construction .............. 34

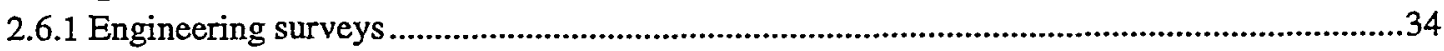

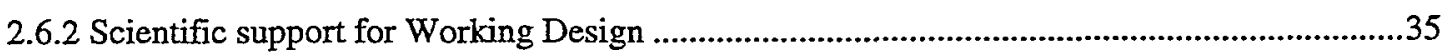


2.6.3 Development of Working Design for construction .......................................................................35

2.7 Construction, Operation, and Closure of the $\mathrm{RW}$ Repository............................... 35

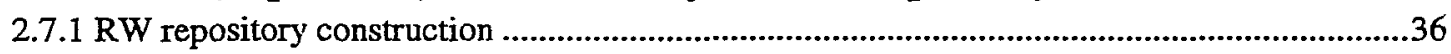

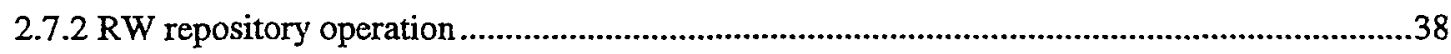

2.7.3 Permanent closure of RW repository .................................................................................38

CHAPTER 3. DESIGN AND EXPLORATION WORK IN THE BUFFER ZONE OF

PA "MAYAK" ...................................................................................................................40

3.1 Status of Prospective Sites for an $R W$ Repository at $P A$ “Mayak" ..................... 40

3.2 Development of the Declaration of Intent .................................................................. 42

3.2.1 Main types of survey and research work ..............................................................................42

3.2.2 Development of DOI........................................................................................................43

3.3 Development of the JOI for RW Repository of the Borehole Type ..................... 43

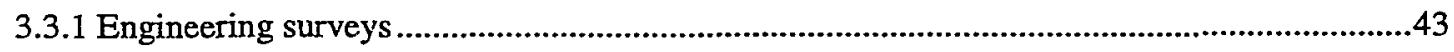

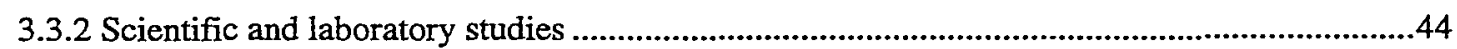

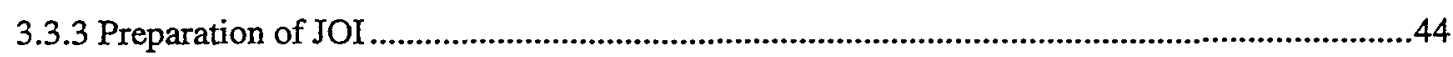

3.4 Underground Borehole Laboratory ..................................................................... 45

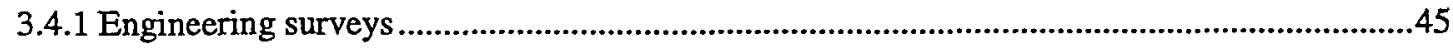

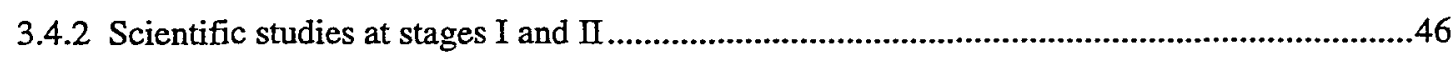

3.4.3 Draft design of underground laboratory ....................................................................................46

3.4.4 Construction of the underground laboratory .............................................................................47

3.5 Scientific Studies in the Underground Laboratory .............................................. 47

3.6 Development of the TEO for the $R W$ Borehole-type Repository .......................... 48

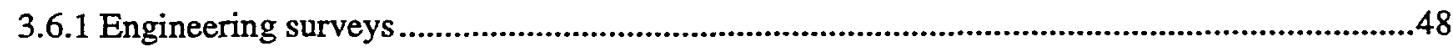

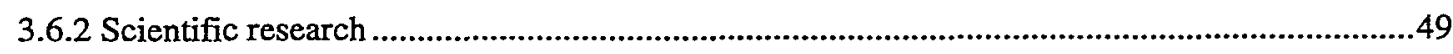

3.6.3 Development of TEO design and construction decisions........................................................49

3.7 Development of Working Documentation for $R W$ Borehole Repository ............. 50

3.7.1 Engineering surveys.............................................................................................................50

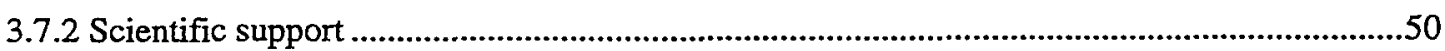

3.7.3 Development of the Working Documentation .....................................................................5

3.8 Construction, Operation, and Closure of RW Borehole Repository...................... 50

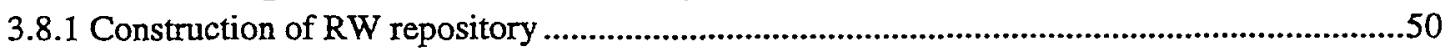

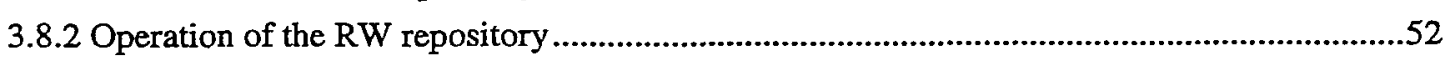

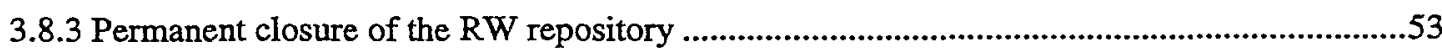




\section{INTRODUCTION}

Les, I have called this an introduction. That's because (1) I assume you will summarize or give some history/interpretation of the project and (2) because it has a figure. Change to Preface if you are just giving acknowledgments, reasons for undertaking the work, etc. 
Figure 1. Add caption. 


\section{CHAPTER 1. THE BASIC PROVISIONS}

\subsection{Russian Approach to the Creation of Geological Repositories for Plutonium-containing Materials and Radioactive Waste}

\subsubsection{Review and analysis of Russian Federation current laws and concepts on radioactive waste management}

The governing system for long-term repositories of radioactive waste (RW) and spent nuclear fuel is founded on the basis of documents, accepted at a state level, including:

- Federal laws and government decrees on RW management;

- Strategy of development of nuclear power engineering;

- The national concept on RW management;

- The concept of RW isolation;

- Federal target programs.

Some of these documents are currently under development and discussion.

The Russian Federation (RF) law On use of atomic energy (dated 20.10.1995) determines the legal grounds and principles of regulation of the use of atomic energy. This law identifies the powers of the authorities of Russia: the President, Federal assembly, Government, subjects of federation and bodies of self-government. It also establishes the rights of organizations and citizens concerning the use of atomic energy together with state and safety regulations for the use of nuclear energy.

Disposal of radioactive waste is allowed only in places specifically intended as repositories, which are constructed on the basis of design or engineering specifications developed by specialized organizations in the RF Ministry of Atomic Energy (Minatom).

The law On radiation safety for population determines legal regulations that ensure radiation safety. This law establishes the order of licensing activity in the field of management with sources of ionizing radiation. Special attention is given to radiation safety controls governing various kinds of work.

The Federal law On radioactive waste management directly concerns the problem of long-term repository and final RW isolation. The draft of this law is under consideration in the State Duma of RF. This law will establish a legal basis for activities related to the management of radioactive waste and is directed at the prevention of harmful effects on people and the environment. The law specifies the following:

- Conduct of the state accounting of RW;

- Definition of the state inventory of RW;

- Development, approval and introduction into practice the state concept of RW management;

- Creation of programs in the field of RW management;

- State ecological examination of pre-design and design documentation; 
- State licensure in the field of management with RW;

- Ecological and geological justification of sites intended for RW repositories.

At the present time, several variants of the concept for RW management in Russia exist in the RF. They were elaborated mainly by VNIPIpromtechnologii (VNIPIPT) experts and first published in 1979. The concepts were repeatedly discussed at scientific and technical councils of Minatom of Russian Federation, sections of the Academy of Sciences, specialized coordinating scientific and technical councils and other meetings.

One concept for reliable radioactive waste isolation in geological formations developed by VNIPIPT in 1993 formulates::

- The objective and tasks of RW management;

- The basic principles of RW management;

- The main stages of RW management

- The state accounting of radioactive waste;

- State regulation of safety;

- Principles of RW isolation in geological formations.

Experts from the lead organizations, VNIPIPT, VNINM, IphCh RAN, and NPO RI, have prepared Basic technical requirements for solidified waste underground repositories in low permeable geological formations. In preparing this document, they used the state standards (e.g., NRB-76, OSP-72, SPORO-85, SNIPs, legislation principles, standards) and practically all materials developed by the International Atomic Energy Association (IAEA) technical-expert committee on underground disposal of waste that were published from 1991-1995.

The structure of legislative controls and governing documents for RW management in the Russian Federation is presented in Fig. 2.

\subsubsection{Design documentation and licensing procedures for design, construction, and operation of an RW geological repository}

Since 1957, the Russian Federation has been a member of IAEA. The governing (normative), legal basis on radioactive waste management was developed taking into account the recommendations and rules of this organization.

Russia has created a system of state regulation for nuclear power safety, which is constantly evolving. This system is presented in The "List of basic standards and normative documents used by Gosatomnadzor of Russia for state regulation of safety in the field of atomic energy application (P-01-01-98).

The obligatory documents that govern use are listed below:

- Federal rules and regulations for use of atomic energy;

- General principles of safety approved by State Supervision of Russia;

- The general documents of Russia State Supervision on licensing, and also other general documents establishing requirements, obligatory for organizations that are carrying out an activity in the field of atomic energy applications; 


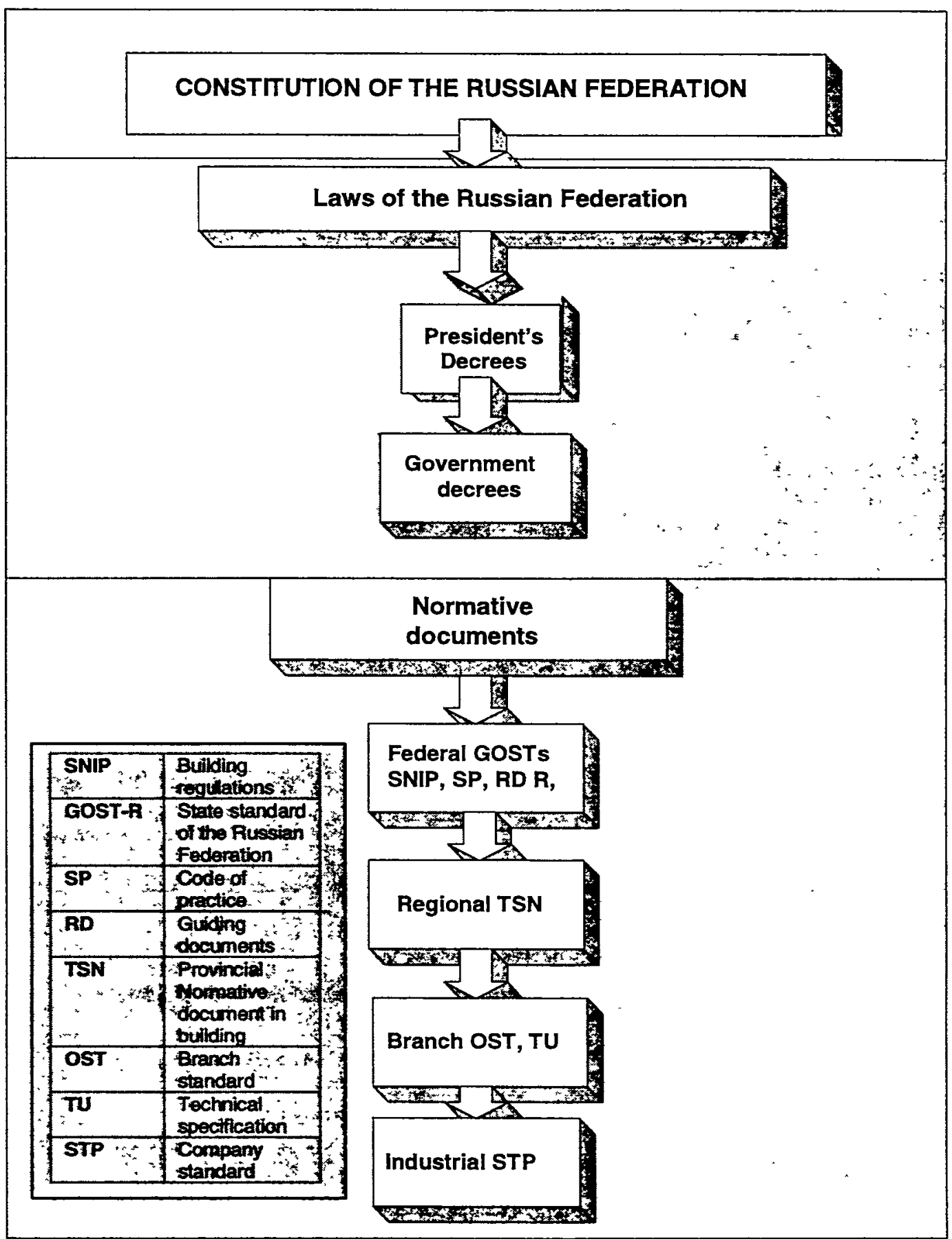

Fig. 2. Hierarchic structure of legislative and normative basis (standards and guides) on RW management in the Russian Federation.

- Normative (standards/specifications/procedural)documents on equipment certification;

- The normative documents approved by other bodies of state regulation of safety, and also federal bodies of the executive authority.

Now the development of normative base is carried out according to regulations and Federal target programs. 
Regulations on development and approval of federal norms and rules in the field of use of atomic energy is the document that determines the order of development, coordination, approval and introduction into action of federal rules and regulations and also introduction of changes and additions. The list of federal rules and regulations in the field of use of atomic energy includes:

- Federal norms and rules on nuclear and radiation (technical aspects) safety approved by State Supervision of Russia;

- Federal norms and rules on radiation safety (sanitary - hygienic aspects), approved by Minzdrav (Ministry of Health) of Russia. Many documents in this section are under reconsideration or are still being developed;

- Federal norms and rules on fire safety.

The general order of development and examination of the documents for construction is determined by the following two-part document::

- Order of development, coordination, approval and structure of justification of investments in construction of enterprises, buildings and structures .(SP 11-101-95);

- Instruction on the order of development, coordination, approval and structure of design documentation for construction of enterprises, buildings and structures (SNIP-11-01-95).

These both documents represent a single whole.

In the investment decision process the design stage of construction, in view of current Russian legislation and foreign practice, consists, as a rule, of three basic stages.

Stage I. Definition of investment objective, purpose and capacity of the facility to be constructed, nomenclature of production, and location in view of customer's basic requirements and conditions. This definition is based on research and studies of financing sources, conditions and means of realization of objectives, and items from the information database. It is used to estimate the opportunities of the investment and achievement of planned technical and economic parameters. Using the decisions made at this stage, the Declaration of Intentions (DOD) is developed.

After obtaining a positive decision on the DOI from a local executive authority, the customer begins to work on the second stage, Justification of Investments (JOD) in construction.

Stage II. Development of the JOI. This is prepared on the basis of the information obtained previously, including requirements of state bodies and interested organizations in sufficient detail to make decisions about expediency of further investments, obtaining preliminary site approval from the appropriate executive body, and development of the design documentation.

Stage III. Development, coordination, examination, and approval of the design documentation, and obtaining an allotment of the ground area for construction based upon the design documentation decision.

Ecological examination. The facilities selected according to the law About ecological examination are subjected to state ecological examination. The documents are accepted for ecological examination only if data are made available on the assessment of the facility's effect on the environment and ecological justification of the facility.

The expert commission must agree that the following requirements are met: 
- Conformity of planned activity to ecological requirements;

- Admissible planned impact on the environment;

- Opportunity to realize the construction objectives;

The RF document Instruction on ecological justification of economic and other activities stipulates:

- Ecological requirements in normative documentation;

- Requirements for ecological justification in pre-investment activity;

- Requirements for ecological justification in pre-design and design documentation for construction of entities of economic and other activity (construction rules and regulations SP 11-101-95 and SNIP 11-01-95);

- Requirements for ecological justification of engineering, technology, and materials;

- Requirements for ecological justification of licenses.

The decree About use of the methodology of risk estimation for quality control of environment and health of population in Russian Federation establishes the obligatory risk estimates using the appropriate methodology approved by the chief sanitary doctor of the RF.

The risk estimates allow the determination of the expediency, priority, and efficiency of environmental protection measures aimed at the reduction of harmful effects on the environment or on population health.

The realization of this decree should be carried out according to Methodical instructions on realization of risk analysis of dangerous industrial facilities (RD 08-120-96).

The basis of the document involves engineering (qualitative) methods of danger analysis using simplified techniques of quantitative risk estimation on the basis of the accepted criteria.

The decree About environment impact assessments (EIA) is developed in conformity with the Federal law About ecological examination. It regulates the estimation of the impact of planned economic and other activity on the environment and the preparation of appropriate documents that form the basis for development of justification documentation for objects of state ecological examination.

The following documents establish the order in which documents are examined and license activity in the field of atomic engineering and industry. They also govern state safety supervision by the State Atom Supervision of Russia.

Rules on making decisions about location and construction of nuclear installations, radiation sources and places of repository regulate the basic processes connected with justification of investments in construction, site selection, development of design documentation, and coordination and approval. The rules are applied to nuclear installations, radiation sources and repositories, and also to nuclear ships and other vessels, transport facilities and conveyances of federal, regional and local significance.

Decisions about the site locations are made:

- For facilities of federal significance by the Government of the RF together with state authorities of the subject of Federation; 
- For facilities of regional significance by government bodies of the subject of Federation;

- For facilities of local significance by the local authority.

Decree about licensing activity in the field of use of atomic energy establishes the order and terms of license activity in the field of use of atomic energy, including RW management during placement in repository, processing, transport, and disposal.

Decree on organization of safety state supervision at use of atomic energy $R D-03-43-98$ is the general document identifying organization for state safety supervision of the use of atomic energy, and is carried out by State Atom Supervision of Russia.

Decree about state control over geological study, rational use and protection of mineral resources lays out state control exercised over geological study, rational use and protection of mineral resources.

The RW geological repository at the Nizhnekansky massif is considered to be an object of Federal significance, and its licensing will require considerable expenses at all construction stages. In particular, for the DOI, there will be public opinion and mass media expenses, and costs in obtaining approval at the regional and local level. At the JOI stage, approval will be required by federal government bodies. These expenses for licensing can be assessed approximately and included in the total expenses for RW geological repository construction.

\subsubsection{Requirements for creation of quality control programs of RW management}

Quality control is always a necessary element in the process of design, development, production, installation and service. This is especially true for ecologically dangerous production and projects, and thus is regulated in state standards.

State standard of the Russian Federation, Model of quality control during design, development, production, installation and service (GOST R ISO 9001-96) includes requirements on such items as the quality of design and survey work, assembly, and service.

With reference to enterprises and processes of RW management, the general document Requirements to the program of quality control at radwaste management $R B-003-98$ _was developed to establish requirements for the quality control program. It is applied to RW management at nuclear installations, radiation sources, in places for repositories and RW repositories.

\subsubsection{Management and organization of work in the RW geological repository project}

Figure 3 presents the organizational structure for design and exploration work on the RW geological repository at the Nizhnekansky massif.

Given the uniqueness and importance of the future construction, highly skilled experts from design and research institutes of Minatom of Russian Federation and the Russian Academy of Sciences, and specialized geological and geophysical organizations of the Siberian region will work on appropriate tasks (Table 1, Fig. 4). VNIPIPT will provide methodical guidance and participate directly in all studies, ensuring uniform direction of work, immediate use of data from geological prospecting and scientific research for development of pre-design and design decisions, the DOI, JOI, and Technical and Economic Justification (TEF) in accordance with construction rules and regulations and State standards for design work. 


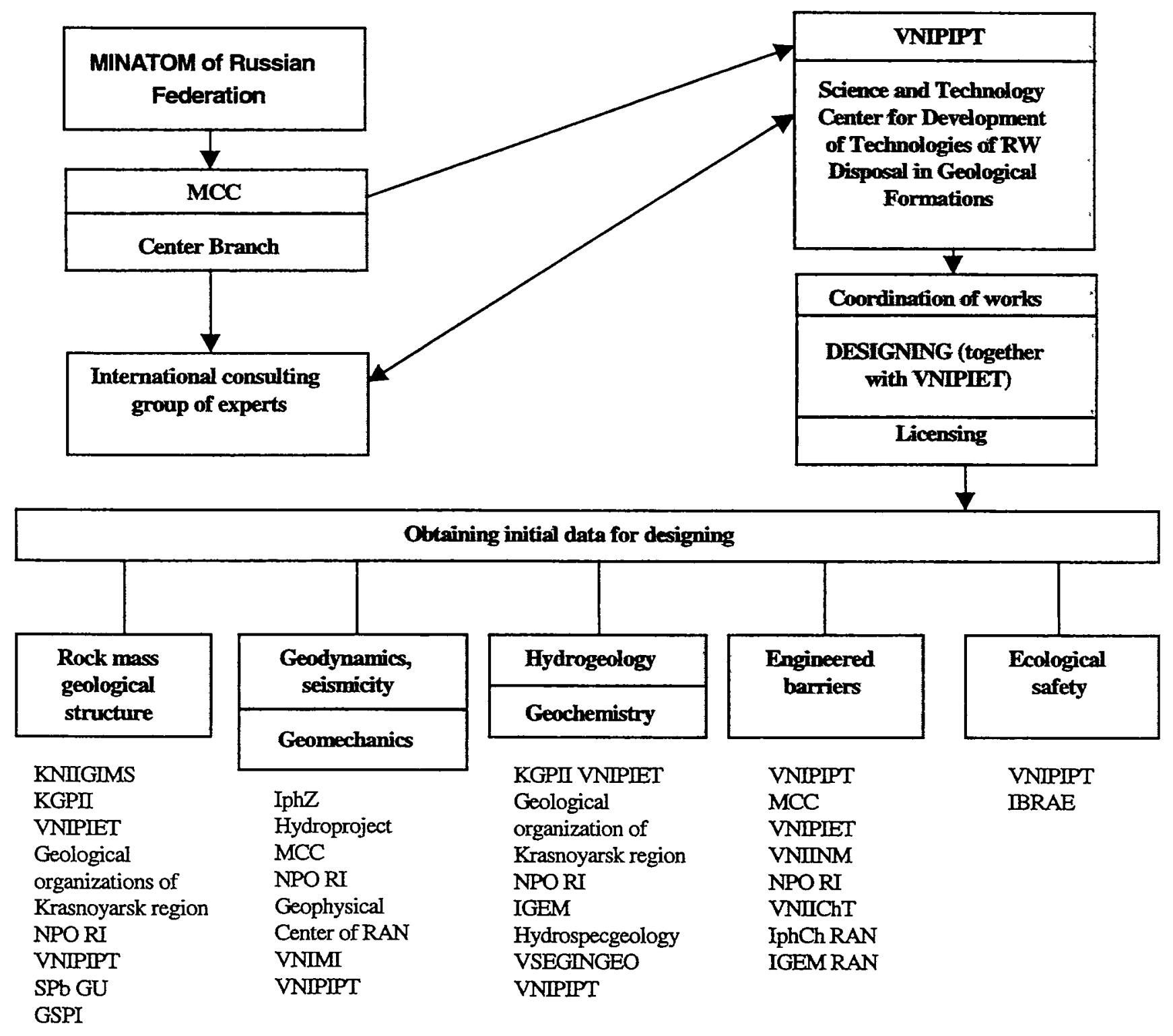

Fig. 3. Scheme of work organization for creating RW underground isolation facility at Nizhnekansky rock massif.

VNIPIPT's role as program coordinator for the RW geological repository is justified by the fact that it is the leading Minatom design organization for underground facilities. VNIPIPT has research, design, and exploration divisions that have specialized in the initial and final phases of the nuclear fuel cycle for 50 years, from mining and processing of uranium ores up to radioactive waste disposal. 
Table 1. Organizations participating in the Nizhnekansky geological repository project.

\begin{tabular}{|l|l|}
\hline VNIPIPT & $\begin{array}{l}\text { All-Russian Design and Research Institute of Production Engineering } \\
\text { (VNIPIpromtehnologii) }\end{array}$ \\
\hline MCC & Mining and Chemical Combine \\
\hline NPO RI & Scientific-Production Association Radium Institute \\
\hline VNIINM & All-Russian Institute of Inorganic Materials \\
\hline VNIPIET & $\begin{array}{l}\text { All-Russian Research and Design Institute of Complex Power Engineering } \\
\text { Technologies }\end{array}$ \\
\hline VNIIChT & All-Russian Research Institute of Chemical Technology \\
\hline IGEM RAN & $\begin{array}{l}\text { Institute of Ore Deposits Geology, Petrology, Mineralogy and Geochemistry } \\
\text { of RAN (RAN = Russian Academy of Sciences) }\end{array}$ \\
\hline Hydroproject & SHC «Institute Hydroproject» \\
\hline IBRAE RAN & Institute of Safe Development of Nuclear Engineering of RAN \\
\hline VNIMI & All-Russian Research Institute of Mine Surveying \\
\hline GSPI & State Specialized Design Institute of Minatom of Russian Federation \\
\hline GC RAN & Geophysical Center of RAN \\
\hline VSEGINGEO & All-Russian Research Institute for Hydrogeology and Engineering Geology \\
\hline SPb GU & St Petersburg State University \\
\hline Hydrospecgeology & Production and Geological Specialized Association \\
\hline KGPII «VNIPIET» & Krasnoyarsk State Research Institute «VNIPIET» \\
\hline KNIIGIMS & Krasnoyarsk Research Institute of Geology and Mineral Products \\
\hline IPhZ RAN & Institute of Physics of Earth of RAN \\
\hline IPhCh RAN & Institute of Physical Chemistry of RAN \\
\hline GOSCENTER «Priroda» & State Scientific-Research and Production Center «Priroda» \\
\hline FSU «Aerogeology» & Federal state unitary «Aerogeology» \\
\hline MGU & Moscow State University \\
\hline GIN RAN & Geological Institute of RAN \\
\hline GEOKHI & Institute of Geochemistry and Analytical Chemistry \\
\hline GO Kr & Geological Organization of Krasnoyarsk region \\
\hline
\end{tabular}

Long-term studies performed by the institute in such fields as conducting nuclear explosions for peaceful purposes, disposal of liquid and solid radioactive waste, rehabilitation of contaminated territories, geomonitoring of underground areas, and containing environmentally hazardous facilities made it possible to develop the database that will be used to justify selection of construction sites and the design of RW underground repositories.

In 2001, a new problem, "Underground isolation of waste from processed SNF" was included in the list of RF Minatom primary goals. This should result in justification and selection of geological sites, optimization of design decisions on underground isolation of solidified waste from processed irradiated nuclear fuel (SNF), including defense programs waste.

\subsubsection{Russian Science and Technology Center Proposed for RW Disposal Technologies}

In order to conduct the Nizhnekansky massif repository program more efficiently, a Russian Science and Technology Center for Development of Technologies for RW Disposal in Geologic Formations is planned (Fig. 3). 
The purpose of the center is to bring together and coordinate laboratories, institutions, companies and organizations that work on the Russian underground isolation site program. The center will analyze Russian waste management scenarios and develop plans, review completed work, and coordinate development of research and engineering projects. The center would also share technologies with foreign laboratories and organizations involved in geologic repository development. Another function of the Center will be system analysis of program requirements and activities. This will provide a basis for activity prioritization and decision-making that will be independent from any other organization.

Forty experts from the institutes and organizations listed in Table 1 and Fig. 4 will be included in the project.

In the course of the Nizhnekansky repository project, the center will provide the overall scientific and methodical guidance and management, prepare progress quarterly reports, work plans, process the documents, obtain permission for open data publications, organize meetings and conferences on problems of RW underground repository development.

\subsection{Basic legal acts and ruling documents}

The laws and documents listed in Table 2 are used during development of the plan for construction of underground RW repositories at Russian sites.

Table 2. RF laws and documents governing construction of underground $R W$ repositories.

\begin{tabular}{|c|c|c|}
\hline № & Description of the document & $\begin{array}{l}\text { Number, date of adoption, } \\
\text { department or official who } \\
\text { has signed the document }\end{array}$ \\
\hline \multicolumn{3}{|c|}{ Federal laws } \\
\hline 1. & Law of RSFSR about "Protection of natural environment" & № 2060-1 of 19.02 .1991 \\
\hline 2. & Law of RF "On ecological examination" & № 174-FZ of 23.11 .1995 \\
\hline 3. & $\begin{array}{l}\text { Law of RF "About use of atomic energy" with supplements and } \\
\text { amendments of } 10.02 .1997 \text {. }\end{array}$ & № $170-F Z$ of 21.11 .1995 \\
\hline 4. & Law of RF "On radiation safety for population" & № 3-FZ of 09.01.1996 \\
\hline 5. & $\begin{array}{l}\text { Law of RF "On inserting amendments in } \mathrm{Cl} .13 \text { of the Federal law } \\
\text { "On ecological examination" }\end{array}$ & № 65-FZ of 15.04 .1998 \\
\hline 6. & $\begin{array}{l}\text { Law of RF "On inserting supplements to Cl.50 of RF Law "On } \\
\text { environmental protection" }\end{array}$ & № 93-FZ of 06.06.2001 \\
\hline 7. & $\begin{array}{l}\text { RF Law "On inserting supplements into Federal Law "On atomic } \\
\text { energy application" }\end{array}$ & № $94-F Z$ of 10.07 .2001 \\
\hline 8. & Law of $\mathrm{RF}$ on radioactive waste management & $\begin{array}{l}\text { Draft under consideration in } \\
\text { the State Duma }\end{array}$ \\
\hline \multicolumn{3}{|c|}{ President's decree } \\
\hline 1. & $\begin{array}{l}\text { "On state strategy of Russian Federation for environmental } \\
\text { protection and ensuring its stable development" }\end{array}$ & № 236 of 04.02 .1994 \\
\hline \multicolumn{3}{|c|}{ RF Government decrees } \\
\hline 1. & $\begin{array}{l}\text { About rules of making decisions on location and construction of } \\
\text { nuclear installations, sources of radiation and places of storage. }\end{array}$ & № 306 of 14.03 .1997 \\
\hline 2. & $\begin{array}{l}\text { About approval of Regulations about licensing in the field of } \\
\text { atomic energy application. }\end{array}$ & № 865 of 14.07 .1997 \\
\hline 3. & $\begin{array}{l}\text { About approval of Regulations on order of state ecological } \\
\text { examination. }\end{array}$ & № 698 of 11.07 .1998 \\
\hline
\end{tabular}


Table 2. (Continued)

\begin{tabular}{|c|c|c|}
\hline 4. & $\begin{array}{l}\text { About approval of Regulations on licensing in the field of } \\
\text { environment protection. }\end{array}$ & № 168 of 26.02 .1996 \\
\hline 5. & $\begin{array}{l}\text { About approval of "Rules on decision-making about location and } \\
\text { construction of nuclear installations, sources of radiation and } \\
\text { places of storage". }\end{array}$ & № 306 of 14.03 .1997 \\
\hline 6. & $\begin{array}{l}\text { About approval of Regulations about state control of geologic } \\
\text { exploration, rational use and protection of mineral resources. }\end{array}$ & № 132 of 02.02 .1998 \\
\hline 7. & $\begin{array}{l}\text { On approval of Federal target program "Nuclear and radiation } \\
\text { safety of Russia in } 2000-2006 \text { " }\end{array}$ & № 149 of 22.02 .2000 . \\
\hline \multicolumn{3}{|c|}{ Norms and rules in the field of nuclear energy application } \\
\hline 1. & $\begin{array}{l}\text { Main sanitary rules for works with radioactive substances and } \\
\text { other sources of ionizing radiation. }\end{array}$ & $\begin{array}{l}\text { OSP }-72187 \\
\text { Chief Sanitary Doctor of the } \\
\text { USSR, } 1987\end{array}$ \\
\hline 2. & $\begin{array}{l}\text { Norms of radiation safety. Hygienic standards } \\
\text { GN - 2.6.1.54-98. }\end{array}$ & $\begin{array}{l}\text { NRB }-96 \\
\text { RF Ministry for Health, } 1999\end{array}$ \\
\hline 3. & Rules for designing regional RW repositories & $\begin{array}{l}\text { Ministry for Health of the } \\
\text { USSR, } 1989\end{array}$ \\
\hline 4. & $\begin{array}{l}\text { Regulations on organization and performing safety analyses of } \\
\text { nuclear installations, sources of radiation and places of storage. }\end{array}$ & $\begin{array}{l}\text { RD-03-13-98 } \\
\text { RF Gosatomnadzor, } 1998\end{array}$ \\
\hline 5. & $\begin{array}{l}\text { Main requirements to contents and scope of surveys when } \\
\text { choosing site and construction site for NPS }\end{array}$ & $\begin{array}{l}\text { Minatomenergo of the USSR, } \\
1989\end{array}$ \\
\hline 6. & Sanitary rules on radioactive waste management & $\begin{array}{l}\text { SPORO }-85 \\
\text { Ministry for Health of USSR, } \\
1985\end{array}$ \\
\hline 7. & $\begin{array}{l}\text { Requirements to the program of quality control during } \\
\text { radioactive waste management. }\end{array}$ & $\begin{array}{l}\text { RB-003-98 } \\
\text { RF Gosatomnadzor, } 1998\end{array}$ \\
\hline 8. & $\begin{array}{l}\text { Safety rules during construction (reconstruction) and mine } \\
\text { technical operation of facilities located in depths not associated } \\
\text { with mining mineral resources. }\end{array}$ & Gosgortechnadzor, 1993 \\
\hline 9. & Temporary regulations on mining and ecological monitoring. & $\begin{array}{l}\text { Gosgortechnadzor, } \\
\text { Minpriroda of } \\
\text { Goskomekologija, } 1997\end{array}$ \\
\hline 10. & $\begin{array}{l}\text { List of primary normative documents used by Gosatomnadzor of } \\
\text { Russia for state regulation of safety in the field of atomic energy } \\
\text { application. }\end{array}$ & $\begin{array}{l}\text { P-01-01-98 } \\
\text { RF Gosatomnadzor, } 1998\end{array}$ \\
\hline 11. & $\begin{array}{l}\text { Instruction on ecological justification of economic and other } \\
\text { activities }\end{array}$ & Minpriroda, 1995 \\
\hline 12. & $\begin{array}{l}\text { Regulations "About methodology approach to risk estimate for } \\
\text { quality control of environment and health of population in } \\
\text { Russian Federation". }\end{array}$ & $\begin{array}{l}\text { Chief Sanitary Doctor of RF, } \\
1997\end{array}$ \\
\hline 13. & $\begin{array}{l}\text { Regulations on organization of state supervision of safety during } \\
\text { atomic energy application. }\end{array}$ & RF Gosatomnadzor, 1998 \\
\hline 14. & $\begin{array}{l}\text { Methodological instructions for risk analysis of hazardous } \\
\text { industrial facilities. }\end{array}$ & $\begin{array}{l}\text { RD 08-120-96 } \\
\text { Gosatomnadzor PФ, } 1996\end{array}$ \\
\hline 15. & $\begin{array}{l}\text { Concept of VNIPIPT on reliable isolation of solidified radioactive } \\
\text { waste in geological formations }\end{array}$ & $\begin{array}{l}\text { Minatom, Gosatomnadzor, } \\
\text { Minecologii, RAN, June, } 1993\end{array}$ \\
\hline 16. & Concept of RF on spent nuclear fuel management & № 94-r of 15.06 .1999 \\
\hline 17. & $\begin{array}{l}\text { Concept of Minatom of Russia on radioactive waste } \\
\text { management }\end{array}$ & № 475 of 03.08 .2000 \\
\hline
\end{tabular}


Table 2. (Continued)

\begin{tabular}{|c|c|c|}
\hline 18. & Primary sanitary instructions on ensuring radiation safety & OSPORB-99 \\
\hline 19. & $\begin{array}{l}\text { Sanitary instructions of designing and operation of nuclear } \\
\text { stations }\end{array}$ & SPORO-85 \\
\hline 20. & Basic provisions for ensuring safety of nuclear stations & $\begin{array}{l}\text { OPR-88 } \\
\text { PNAE G-1-011-97 }\end{array}$ \\
\hline 21. & $\begin{array}{l}\text { Safety instructions for management of nuclear stations' } \\
\text { radioactive waste }\end{array}$ & NP-002-97 \\
\hline 22. & $\begin{array}{l}\text { Collection, processing, storage and conditioning solid } \\
\text { radioactive waste. Safety requirements }\end{array}$ & NP-020-2000 \\
\hline \multicolumn{3}{|c|}{ State and branch standards, construction norms and rules } \\
\hline 1. & $\begin{array}{l}\text { Sites for decontamination and burial of toxic industrial waste. } \\
\text { The basic design principles. }\end{array}$ & SNIP 2.01.28-85 \\
\hline 2. & $\begin{array}{l}\text { Manual on designing sites for decontamination and burial of } \\
\text { toxic industrial waste. }\end{array}$ & $\begin{array}{l}\text { to SNIP } \\
2.01 .28-85\end{array}$ \\
\hline 3. & Engineering surveys for building. The basic principles. & SNIP 11-02-96 \\
\hline 4. & Engineering-ecological surveys for building. & SP 11-102-97 \\
\hline 5. & Building in seismic areas. & SNIP $11-7-81^{\bullet}$ \\
\hline 6. & Underground drifts. & SNIP II- $94-80$ \\
\hline 7. & Engineering surveys for building. & SNIP 1.02.07-87 \\
\hline 8. & Protection of structures against corrosion. & SNIP 2.03.11-85 \\
\hline 9. & Protection of drifts from underground and surface waters & SNIP 2.06.14-85 \\
\hline 10. & $\begin{array}{l}\text { Instruction about order of development, co-ordination, approval } \\
\text { and contents of design documentation for construction of } \\
\text { enterprises, buildings and structures. }\end{array}$ & SNIP 11-01-95 \\
\hline 11. & Geophysics of dangerous natural impacts. & SNIP 22-01-95 \\
\hline 12. & $\begin{array}{l}\text { Order of development, co-ordination, approval and contents of } \\
\mathrm{JOI} \text { of enterprises, buildings and structures. }\end{array}$ & SNIP 11-101-95 \\
\hline 13. & Engineering-geologic surveys for building. & SNIP 11-105-97 \\
\hline 14. & Engineering-hydrometeorological surveys for building. & SP 11-103-97 \\
\hline 15. & $\begin{array}{l}\text { Engineering security for territories, buildings and structures from } \\
\text { hazardous geologic processes. }\end{array}$ & SNIP 1.01.15-90 \\
\hline 16. & $\begin{array}{l}\text { Order of development, and contents of section "Engineering- } \\
\text { technical measures of civil defence. Actions to prevent } \\
\text { emergency case". }\end{array}$ & SP 11-107-98 \\
\hline 17. & $\begin{array}{l}\text { Instruction on engineering surveys in rock drifts intended for } \\
\text { location of entities of national economy. }\end{array}$ & SN 484-76 \\
\hline 18. & Engineering-ecological surveys for water power constructions. & VSN 34.2-88 \\
\hline 19. & $\begin{array}{l}\text { System of standards in the field of environmental control and } \\
\text { advanced use of natural resources. The basic principles. }\end{array}$ & $\begin{array}{l}\text { GOST } 17.0 .0 .01-76 \\
\text { (ST CMEA 1364-78) }\end{array}$ \\
\hline 20. & Transport of radioactive substances. Terms and definitions. & GOST 12916-89 \\
\hline 21. & $\begin{array}{l}\text { Quality systems. Quality model during designing, development, } \\
\text { production, installation and service. }\end{array}$ & GOST R NSO $9001-96$ \\
\hline 22. & $\begin{array}{l}\text { Collection. storage, treatment and burial of radioactive waste. } \\
\text { Terms and definitions. }\end{array}$ & GOST R 50996-96 \\
\hline 23. & $\begin{array}{l}\text { Radiation control during radioactive waste burial. Description of } \\
\text { monitored parameters. }\end{array}$ & GOST 12.1.048-85 \\
\hline 24. & High-level solidified waste. General technical requirements. & GOST R 50926-96 \\
\hline
\end{tabular}


Table 2. (Continued)

\begin{tabular}{|c|c|c|}
\hline 25. & Bitumenized radioactive waste. General technical requirements. & GOST R $50927-96$ \\
\hline 26. & $\begin{array}{l}\text { Sites for temporary storage of solid radioactive waste. General } \\
\text { technical requirements. }\end{array}$ & $\begin{array}{l}\text { OST } 95 \\
10516-95\end{array}$ \\
\hline 27. & $\begin{array}{l}\text { Storage for solid radioactive waste. General technical } \\
\text { requirements. }\end{array}$ & $\begin{array}{l}\text { OST } 95 \\
10517-95\end{array}$ \\
\hline 28. & $\begin{array}{l}\text { Radioecological passport of specialized facility for radioactive } \\
\text { waste management. Basic principles. }\end{array}$ & GOST R 50888-96 \\
\hline 29. & Safety in emergency case. Basic principles. & GOST R 22.0.01-94 \\
\hline 30. & Safety in emergency case, protection of population. & GOST R 22.3.03-94 \\
\hline 31. & $\begin{array}{l}\text { Safety in emergency case, causes of natural emergency cases. } \\
\text { Knocking factors. Description of knocking factors and their } \\
\text { parameters. }\end{array}$ & GOST R $22.0 .06-95$ \\
\hline 32. & $\begin{array}{l}\text { Safety in emergency case, causes of technogenic emergency } \\
\text { cases. Classification and description of knocking factors and } \\
\text { their parameters }\end{array}$ & GOST R 22.0.07-95 \\
\hline 33. & Methods of laboratory definition of physical characteristics. & GOST 5180-84 \\
\hline 34. & $\begin{array}{l}\text { Grounds. Sampling, packaging, transport and storage of } \\
\text { samples. }\end{array}$ & GOST 12071-84 \\
\hline 35. & Grounds. Methods of statistical processing of test results. & GOST 20522-96 \\
\hline 36. & $\begin{array}{l}\text { Hard rocks. Methods of definition of ultimate strength at axial } \\
\text { compression.. }\end{array}$ & GOST 21153.2-84 \\
\hline 37. & $\begin{array}{l}\text { Hard rocks. methods of definition of ultimate strength at uniaxial } \\
\text { tension. }\end{array}$ & GOST 21153.3-85 \\
\hline 38. & Grounds. Methods of field test of permeability.. & GOST 23278-78 \\
\hline 39. & Grounds. Laboratory tests. General provisions. & GOST 30416-96 \\
\hline 40. & $\begin{array}{l}\text { Methodical instructions on ensuring radiation safety } \\
\text { requirements for mining, reprocessing of mineral raw materials } \\
\text { at enterprises (organizations) of ore mining and mineral } \\
\text { industries referred to radiation hazardous production. }\end{array}$ & $\begin{array}{l}\text { Approved by Decree of } \\
\text { Gosgortechnadzor } \\
\text { № } 35 \text { of } 14.10 .97\end{array}$ \\
\hline 41. & $\begin{array}{l}\text { Methodical recommendations for definition of physical and } \\
\text { mechanical properties of solid and semisolid rocks. }\end{array}$ & $\begin{array}{l}\text { P-761-82 } \\
\text { Hydroproject }\end{array}$ \\
\hline 42. & $\begin{array}{l}\text { Guide on engineering-geologic surveys for building underground } \\
\text { hydraulic engineering structures. }\end{array}$ & $\begin{array}{l}\text { P-771-82 } \\
\text { Hydroproject }\end{array}$ \\
\hline 43. & $\begin{array}{l}\text { Recommendations for a method of creation of specialized } \\
\text { engineering-geologic models for calculations and studies of rock } \\
\text { foundations. }\end{array}$ & $\begin{array}{l}\text { P-830-85 } \\
\text { Hydroproject }\end{array}$ \\
\hline 44. & $\begin{array}{l}\text { Guide on engineering-geologic documentation for building and } \\
\text { operation of hydraulic engineering structures. }\end{array}$ & P-901-1-993 Hydroproject \\
\hline 45. & $\begin{array}{l}\text { Recommendations on engineering-geologic examinations for } \\
\text { construction of underground civil and industrial constructions. }\end{array}$ & Moscow, Strojizdat 1987 \\
\hline 46. & $\begin{array}{l}\text { Recommendations on application of engineering geophysics for } \\
\text { study of deformation properties in rock massifs. }\end{array}$ & Hydroproject 1985 \\
\hline 47. & $\begin{array}{l}\text { Recommendations for study of stressed state in rocks by } \\
\text { seismoacoustic methods. }\end{array}$ & Hydroproject 1986 \\
\hline 48. & $\begin{array}{l}\text { Guide on the method of study of physical-mechanical properties } \\
\text { and stressed state in rock masses during engineering surveys in } \\
\text { drifts intended for location of national economy entities. }\end{array}$ & Moscow, Strojizdat, 1977 \\
\hline
\end{tabular}




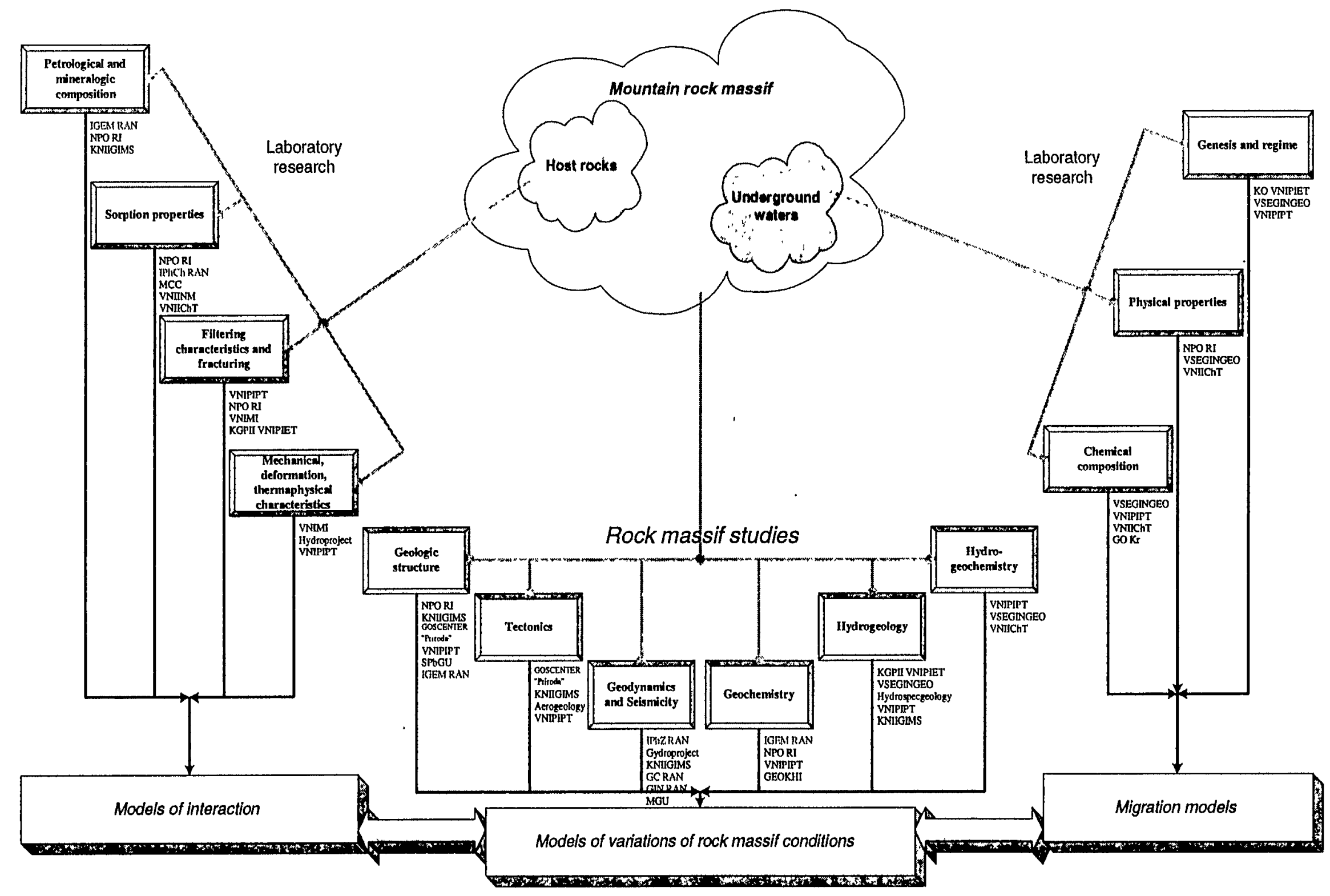

Fig. 4. Directions of research on RW underground isolation. 


\subsection{Engineering-Geologic Survey for Construction of the Site for Underground RW Isolation}

The underground repository sites for solidified RW are multibarrier systems of isolation where engineered barriers play a limited temporal role. Natural barriers-enclosing rocks-are the main isolating surroundings, which maintain their properties during thousands and millions of years. Thus, the geologic studies of the designs for repository sites should be aimed at detailed and reliable data for forecasting safe RW disposal. The model of the RW repository life cycle is presented in Fig. 5.

The selection procedure for RW construction sites includes a site search of the district, listing proposed sites for construction followed by selection of promising sites, and final choice and confirmation from among the alternative subsites (Fig. 6).

To choose the section and then a promising site, it is necessary to analyze the geologichydrogeologic conditions of the district and carry out a number of investigations (e.g., geologic survey, surface geophysical study, deep drilling). After the site is chosen, it is necessary to conduct more detailed geologic-geophysical and hydrogeologic investigations, perform deep drilling, and construct the underground laboratory. The data obtained from complex scientific studies in the special underground laboratory are the final determiners of site suitability for RW isolation.

The methods, composition, and volume of engineering-geologic work are defined by the following factors: specific features of the sites being designed, stage of the design-exploration work, complexity and details of the study of the geologic conditions on the site of underground facility construction. In all cases, the studies must be comprehensive and detailed enough to solve the main tasks at each stage of design (Fig. 7).

Maximum information and reliability of the geologic-exploration data is especially important at the first stages of work. This facilitates optimal design decisions and excludes the unexpected increases in the cost of construction that occur when previously undetermined engineeringgeologic complications are revealed.

According to item 3.3 of the Concepts of $R F$ Minatom for radioactive waste management in Russia (order № 475 of 03.08.2000), territories of the enterprises where work with radioactive materials are now or were being carried out previously should be selected whenever possible as sites for RW storage and disposal. This also reduces ecological risk and monitoring cost.

According to item 2.6 .5 of the Russian Federation concepts on SNF management (№ 94-r of 15.06.1999), a number of prime and prospective sites for disposal of radioactive waste from SNF processing were selected: among them were the industrial site of PA "Mayak" and the Nizhnekansky granitoid massif. 


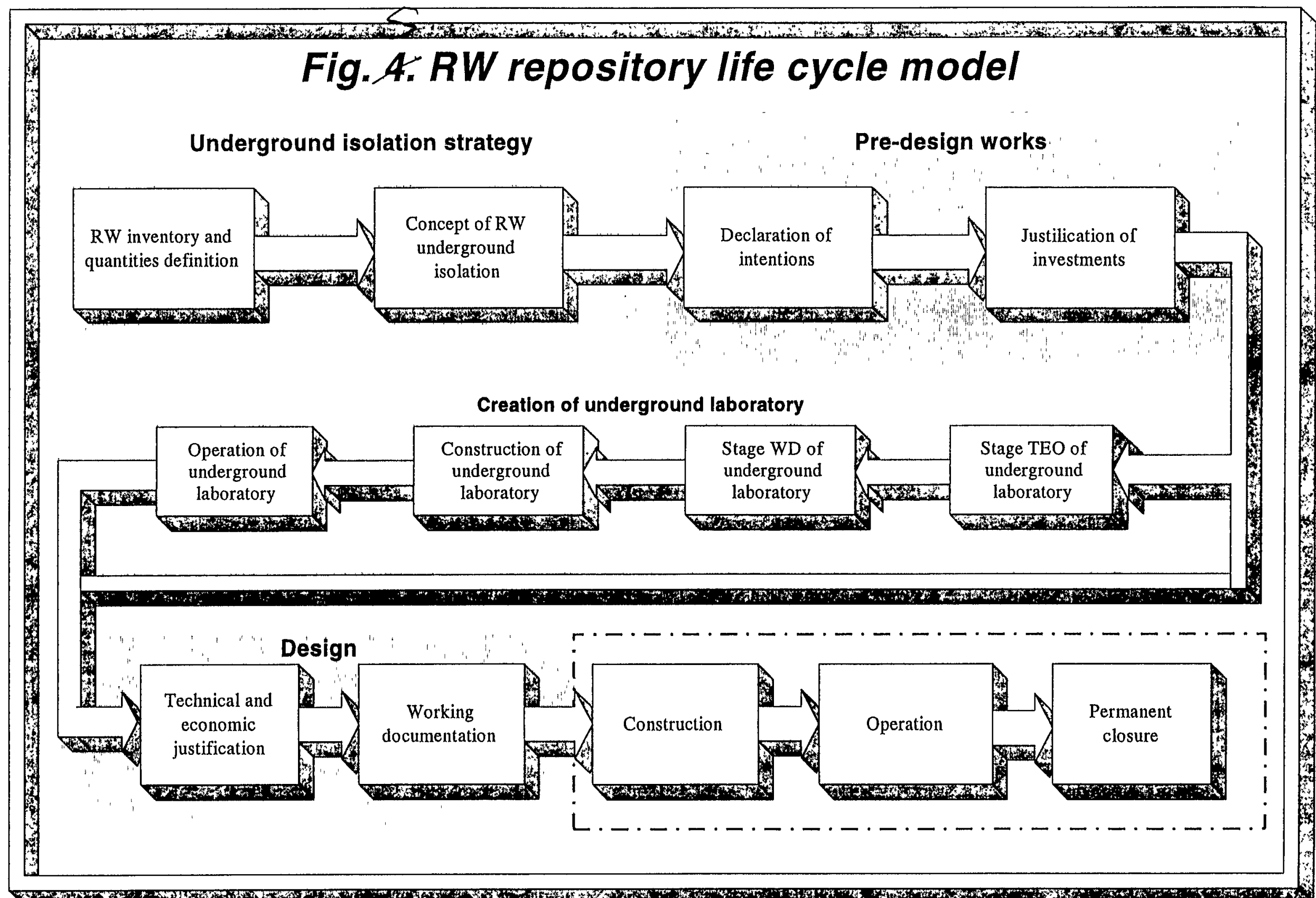




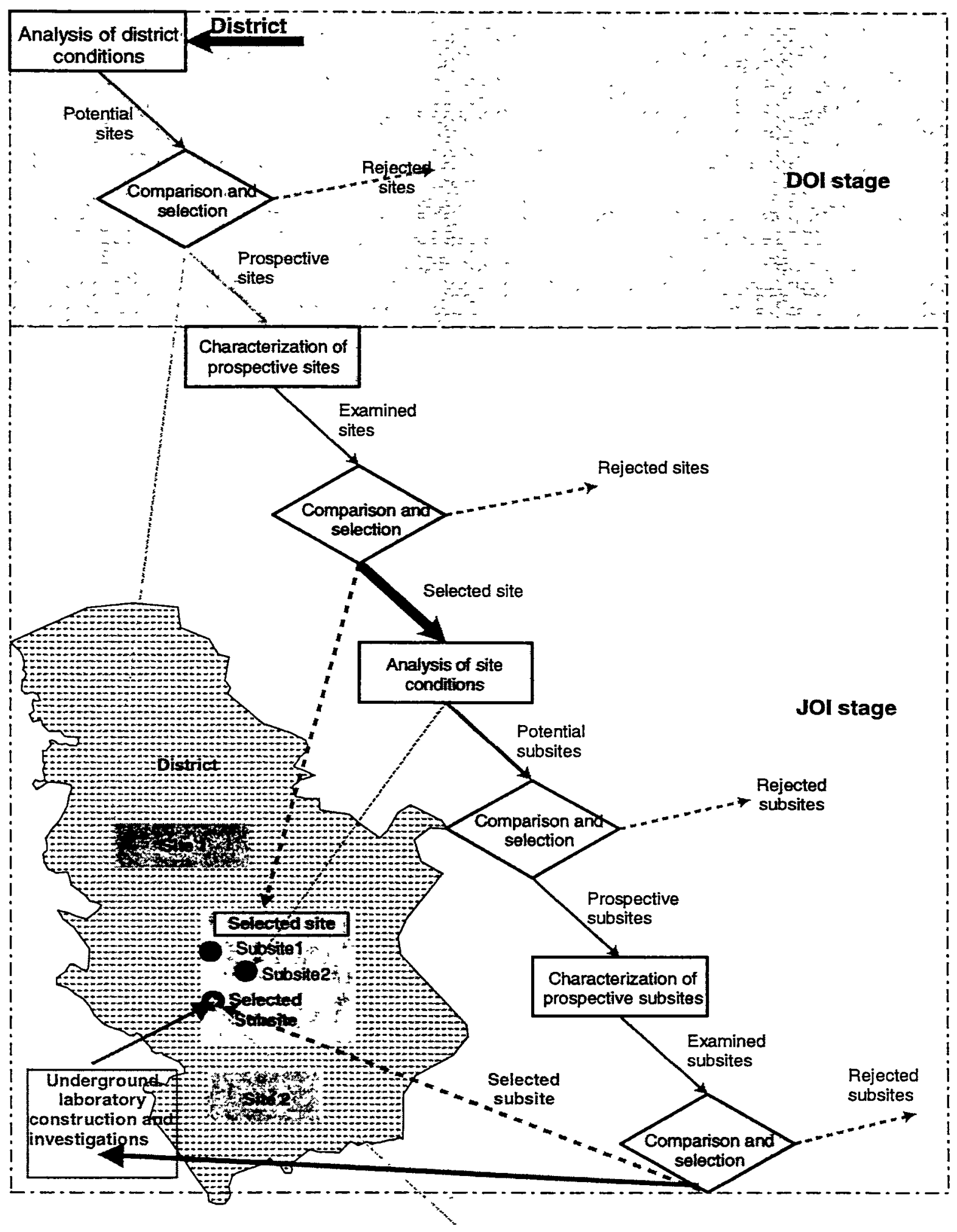

Fig. 6. Algorithmic scheme of site selection for $\mathrm{RW}$ isolation. 


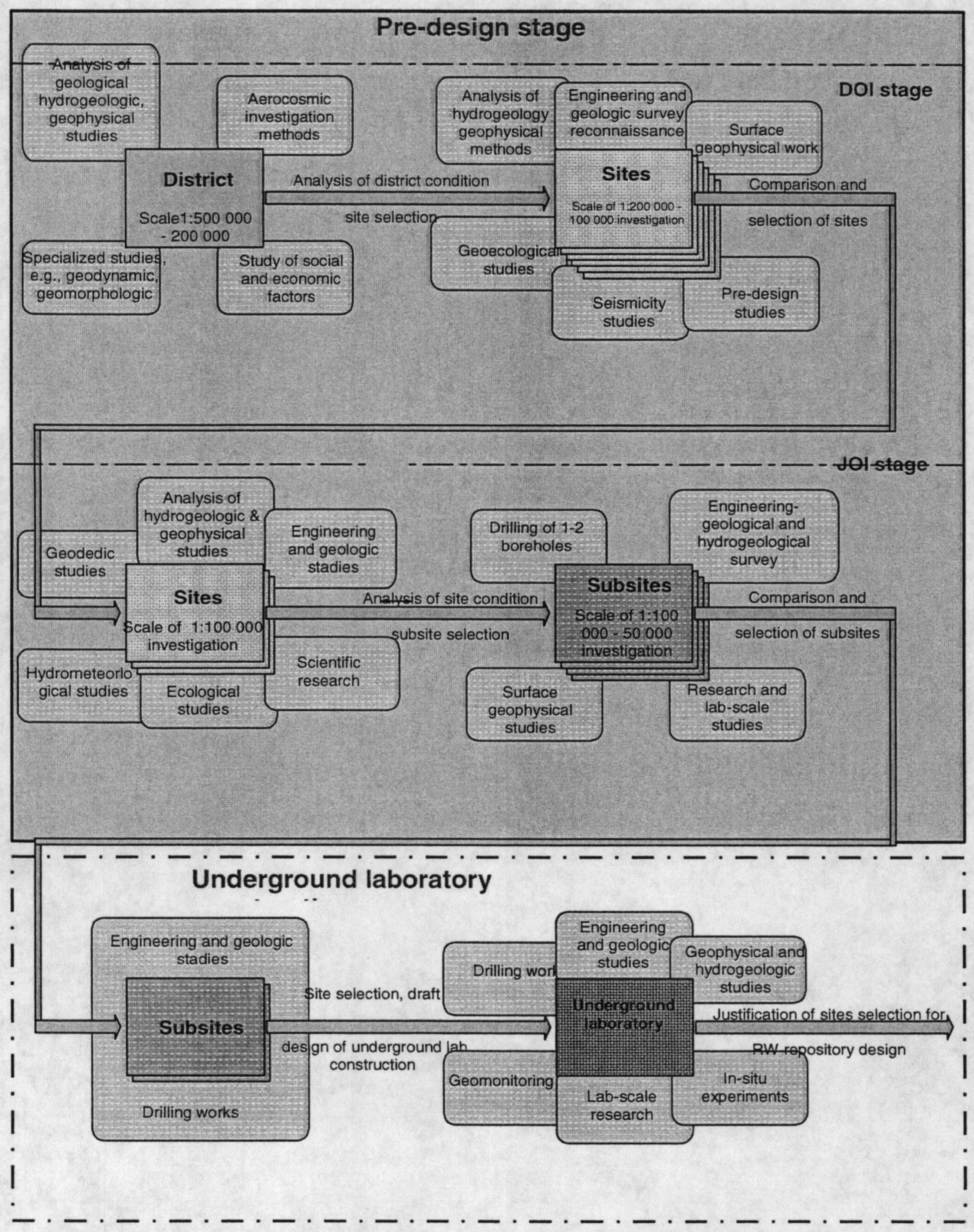

Fig. 7. Scheme of research and design-survey works to justify site selection. 


\section{CHAPTER 2. DESIGN SURVEY AND SCIENTIFIC RESEARCH IN THE NIZHNEKANSKY MASSIF}

\subsection{Investigation of Promising Sites at the Nizhnekansky Massif}

\subsubsection{Background}

At the end of the 1980s, VNIPIPT began research in MCC's Zheleznogorsk and Krasnoyarsk region to assess the possibility of building the repository for Federal RW storage at that location.

Global geological structures were studied within a radius of $500 \mathrm{~km}$ from MCC (West-Siberian plate, East-Siberian platform, Altai-Sajany orogenic region). Prospective geological formations were selected and their potential evaluated.

The analysis of geological data has shown that the most applicable structure in which to search for a suitable RW storage site is the Yenisei ridge, where the foundation rock of the ancient Siberian platform is exposed.

Later, a group of experts from organizations and enterprises of RF Minatom, the Ministry for Science, Russian Academy of Sciences, and organizations of the Krasnoyarsk region was formed to study this structure (VNIPIPT, NPO RI, MCC, KGPII VNIPIET, SPb GU, GIN RAN, IGEM RAN, Kf GOSCENTER "Priroda", KNUGIMS).

At the first stage, the search area was about $9000 \mathrm{~km}^{2}$ and covered the southern part of the Yenisei ridge. The assessment for constructing the RW repository within this area was performed in several stages. At each consecutive stage, the area subject to the investigation was further limited, while the complex of investigation methods and the extent of detail were expanded. The region's metamorphic and magma rock masses were considered to be the most favorable formations. This determined the priority of tectonic criterion, i.e., to identify the most monolithic and sufficiently voluminous blocks of rocks remote from the active tectonic zones.

The complex investigations performed were based on the summary and analysis of literature published and archival data on the geological and geophysical studies of this region, which included topography and geodetic plans, space surveys, and reconnaissance missions.

This work allowed us to define individual blocks of crystalline rocks with small disturbances in the southern part of the Yenisei ridge suitable for building the RW underground disposal facility. According to geophysical, structural, and tectonic data, as well as a rating-based evaluation of socioeconomic, geological, and other indicators, the region of the Nizhnekansky granitoid rock mass possesses major advantages for repository construction.

The Nizhnekansky rock massif belongs to the southern part of the Yenisei ridge in the drainage basin of the Kan river. It is one of the largest granitoid massifs of Central Siberia with an exposed area of more than $1500 \mathrm{~km}^{2}$ (with a total area of as much as $3500 \mathrm{~km}^{2}$ ). It is made up of granitoids of various compositions, primarily of very strong biotite granites and granodiorites.

The work performed in 1994-95 was based on methods such as structural-geomorphological, long distance (limited aerial photos and seismic work), and geophysical and hydrogeological 
studies (the latter not very large in scope). The engineering and geological properties of the granitoid rock mass were also modeled.

Several other potential construction sites for the RW disposal were also defined in the northern part of the Nizhnekansky massif and adjacent areas (Fig. 8).

\subsubsection{Current status}

In subsequent years, the lack of necessary funding for complex work under conditions of the taiga interrupted the step-wise organization of exploratory activities. Instead of the geological and geophysical field work originally planned, activities were concentrated at rather small sites located in the confluence of the Bolshoy and Maly Itat rivers. The method of audiomagnetotellurium probing (AMTP) became the primary method. Seismic prospecting, gravity studies, geological and hydrogeological surveys were conducted on a small scale rather than cancel them altogether, and a number of boreholes were drilled.

The analysis of engineering-geological and hydrogeological conditions of prospective sites has shown that the Verhner-Itatsky site is the most preferable with regard to geological conditions.

The latest examinations carried out in regions of the Verhne-Itatsky site show that the site is characterized by considerable inhomogeneity and tectonic disturbance, and a detailed and complex study of its internal structure is needed. The composite tectonic conditions and weak predictability of heat and mass transfer processes under these conditions in fractured mediums equalize, to some extent, the prospects of the Verhne-Itatsky and Yeniseisky sites. These alternative sites require further examination of their suitability as RW disposals.

Verhne-Itatsky site. The Verhne-Itatsky site, with an area of about $50 \mathrm{~km}^{2}$, is situated in the confluence of the Bolshoy and Maly Itat rivers at the distance of about $30 \mathrm{~km}$ from the MCC in the area in the taiga that has no infrastructure. There are widely spread granitoids of the Nizhnekansky rock mass; and granitized host rocks of Pre-Cambrian age are also present. Based on recent investigations, the site area is typified by a diverse set of granitoid rocks and strong tectonic dislocation in the regional parts.

At present, four boreholes 174-705 m deep have been drilled at the site. Borehole K-2 is still being drilled, and a large complex of geophysical and hydrogeological research will be carried out there.

Yeniseisky site. The Yeniseisky site, with area of $36 \mathrm{~km}^{2}$, has a developed infrastructure, and is located $7 \mathrm{~km}$ from MCC. It is formed by granitoids of the Nizhnekansky intrusion and gneissess of Archean age.

The morphology of the site terrain is similar to that of the Verhne-Itatsky. The gneisses' and granitoids' physico-mechanical properties are similar. At the same time, gneisses have a more diverse mineral composition vs. granitoids, which might be important for radionuclide sorption. The Yeniseisky site can be regarded as an alternative option.

Site selection for the RW geological repository within the boundaries of these larger areas can be made only after large-scale geological and geophysical investigations and boreholes are drilled, according to the program especially developed for the project. 


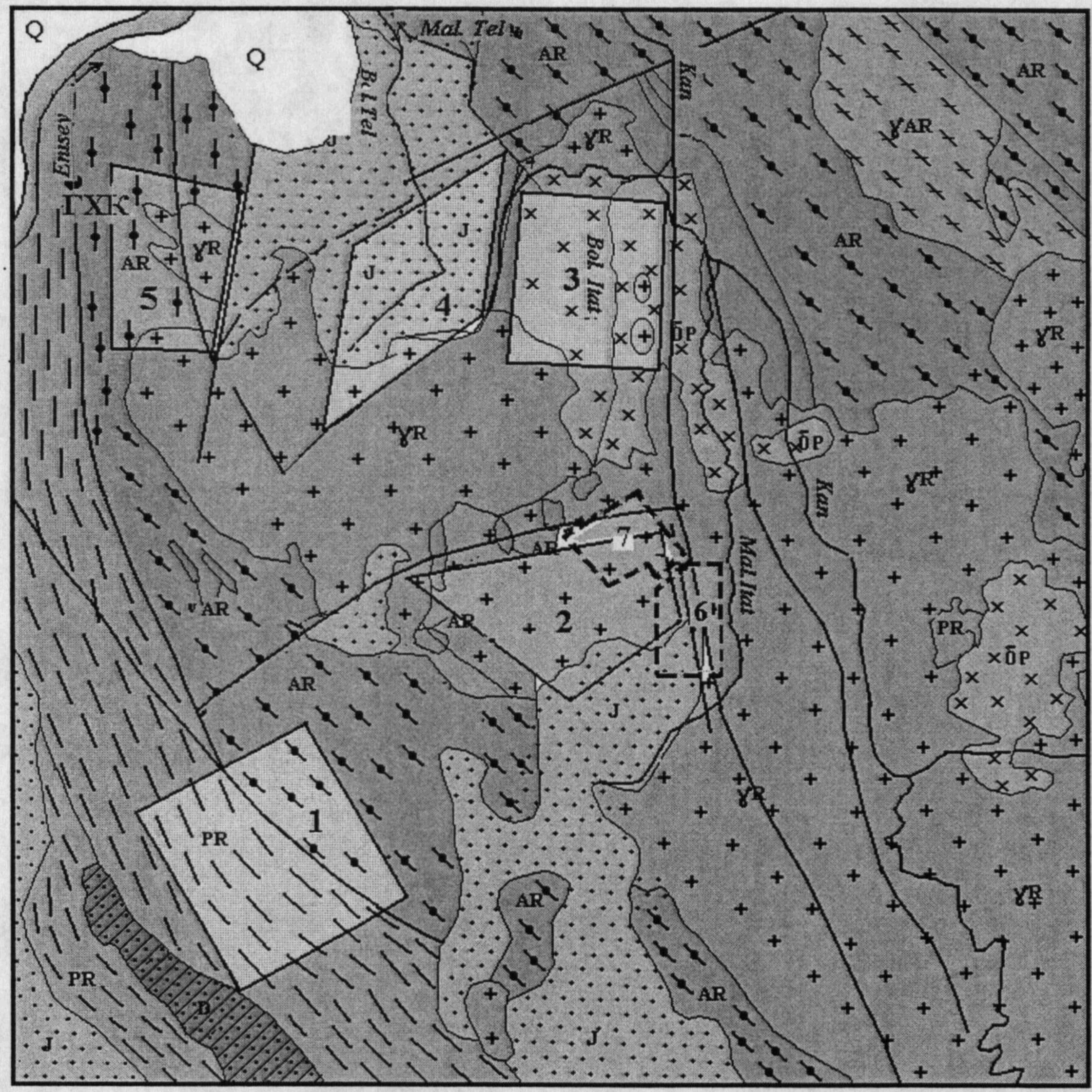

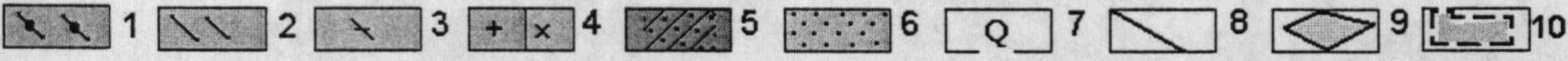

1-gneiss complex(AR): 2 - gneiss complex with amphibolitees (PR): 3 - orthoclasic granites (AR): 4- granitoids of Nizhnekansky complex (PR); granite - leucogranite (ieft) and diorite granodiotite (right); 5 - complex of sedimentary bed - rocks (D); 6- complex of sedimentary bed - rocks (J); 7- sediments (Q); 8- tectonic disturbances; 9- prospective sites; 1 - South: $\mathbf{2}$ - Verchne - Itatsky; 3 - Nizhne - Itatsky; 4 -Telsky; 5- Eniseysky; $\mathbf{1 0}$ - sites of geological investigation bi AMTR 6-Kamenny; 7-Itatsky.

Fig. 8. Prospective sites for creation of RW geological disposal in the area of the Nizhnekansky rock massif. 


\subsection{Development of the Declaration of Intent}

Engineering surveys for the "Declaration of Intent" must be a complex study of the natural and anthropogenic conditions of the region, the district, the site and attempt to forecast potential changes of these conditions in interrelation with the construction facilities.

Hydrogeologic, geologic, and seismic conditions in the district of future construction are studied for this purpose as well as the state and properties of the composing rocks, and how uniformly they are distributed. Geologic surveys are conducted on a scale of 1:5000000-1:200000 and larger by the RF Ministry of Natural Resources (MNR), using the existing normative documents (including seismic estimation of the district), results of specialized and regional hydrogeologic, engineering-geologic, geocryologic, geoecological, and other investigations (Fig. 7).

Scenarios describing different potential emergencies are being developed for preliminary assessments of ecological safety.

This allows definition of districts and sites for the engineering-geologic investigation using criteria specially developed by VNIPIPT.

\subsubsection{Survey and research work}

The exploration and research work needs to include:

- Analysis of physical-chemical, geologic-geophysical, hydrogeologic and topographic materials of previous investigations, results of exploration for mineral resources, decoding of space- and aerial photographs of the territory under study. The districts and sites of mineral exploration are not identified very well. As a result, potential geologic formations, districts and sections need to be defined for construction of underground RW repository sites.

- Engineering-geologic and hydrogeologic study of potential suitable sites by the method of experimental observation.

- Surface profile geophysical survey over an area no less than $100-150 \mathrm{~km}^{2}$ for each section or aero-geographic study.

- Seismic assessment of the territory with definition of seismically active fractures according to stock materials, decoding of space- and aerial photographs.

- Assessment of the ecological status of the territory under study from the point of view of potential construction of RW repository sites

- Laboratory studies of lithologic-petrographic features and physical-mechanical properties of rock samples, chemical composition of underground water and water-soluble gases selected during the engineering-geologic investigation.

The investigations should characterize the following aspects of the construction site:

- Physical-geographic conditions;

- Geologic-geophysical study;

- Geologic structure;

- Geodynamic and seismic processes;

- Hydrogeologic conditions; 
- Ecological status of the district;

- Petrophysical, geochemical and physical-chemical properties of the main rock types;

- Chemical composition of underground water and water-soluble gases.

This forms the basis for:

- Zoning the territory according to degree of the suitability of geologic formations for underground RW disposal;

- Justification and choice of the site (sites) for further investigations;

- Development of the preliminary engineering-geologic models of potential sections for construction;

- Preliminary forecast of potential changes in the environment and its components during construction of the RW repository.

\subsubsection{Development of DOI for construction of repository site and underground laboratory}

This portion of the work includes information needed for design and construction, assessment of environmental effects, and expert opinions. The design and scientific investigations at this stage include:

- Assessment of natural and economic conditions of the construction district;

- Design and construction solutions for the RW repository facility;

- Preliminary assessment of the reliability of engineered and geochemical barriers;

- Development of the preliminary design of the underground laboratory;

- Definition of the main direction of investigations in the underground laboratory;

- Extensive assessment of the ecological safety of underground RW isolation;

- Definition of the approximate and calculated cost of the underground laboratory and future repository site;

- Development of the program of exploration and design work for the next phase of RW disposal design.

Based on the completed investigations, the DOI for construction of the RW repository site at the Nizhnekansky massif will be elaborated. The expert's conclusion will be compiled, and the DOI confirmed by the local and state authority bodies after the investigations are completed. Labor requirements for the DOI stage are estimated at 92 man-years (Table 3).

\subsection{Development of the Justification of Investment}

This JOI defines the construction of the underground repository site and the underground laboratory.

The engineering survey for preparation of the JOI includes obtaining the required data sufficient to substantiate the suitability of the site, and that of the construction subsite (or subsites) within the main site. The survey is required for making principal layout and design decisions on the RW repository site, and its engineering safety and for preliminary locations of the surface and 
underground facilities. At this stage, the assessment of the environmental effects of repository construction and operation is of special importance.

\subsubsection{The engineering survey}

The engineering survey at this and subsequent stages includes engineering-geodesic, engineering-geologic, engineering-hydrometeorologic and engineering-ecological surveys and laboratory work. The scale of the survey is 1:100000 to 1:50000 (Fig. 7).

Engineering-geodesic survey. The engineering-geodesic survey includes topographic-geodesic materials; data on relief of the area under study (including bottoms of water flows and water bodies); location of existing buildings and construction (surface and underground); elements of planning required for complex assessment of natural and anthropogenic conditions of the territories under study; and descriptions of design, construction, and operation of the facilities.

The engineering-geodesic survey at the JOI stage includes:

- Collection and treatment of topographic-geodesic, cartographic, aerial photography and other data from previous years;

- Reconnaissance of the territory;

- Geodesic assistance to engineering-geologic study.

Engineering-geologic survey. The engineering- geologic survey provides a complex study of the site, the supposed subsites for construction including relief, geologic structure, geomorphologic and hydrogeologic conditions, presence of mineral resources, composition, state and properties of rocks, geologic and engineering-geologic processes, and a forecast of potential changes in the hydrogeologic conditions in view of interaction between the designed facilities and the geologic media.

The engineering-geologic survey includes:

- Analysis of data of geologic-geophysical and hydrogeologic research, including results of mineral resources exploration;

- Geologic and engineering-geologic survey of potential sections;

- Structural-geomorphologic studies;

- Surface geophysical studies of the promising sites (seismic-, gravimetric-, magnetic- and electric prospecting);

- Assessment of geodynamic activity of tectonic structures of the district, sites and their seismicity;

- Hydrogeologic surveys of sites;

- Drilling of one or two prospecting boreholes of 1000-1500 m deep; two to three boreholes 100-300 m deep; five to six boreholes up to $100 \mathrm{~m}$ at each section accompanied by a whole complex of geologic, geophysical, and hydrogeologic investigations. The choice of drilling points is defined by the results of geologic-geophysical investigations;

- Assessment of sites under investigation for the presence of mineral resources on the basis of geologic surveys, drilling results, and laboratory studies of rock and underground water samples; 
- Preliminary estimates of the strain state of rocks in the potential sites according to geologicgeophysical data and laboratory studies.

Engineering-hydrometeorologic survey. The survey is to ensure complex study of the hydrometeorologic conditions of the district and sites where construction is planned, in order to forecast potential changes.

It is necessary to study:

- Hydrogeologic regime of rivers, lakes, swamps, river mouths, temporary water flows;

- Climatic conditions and some meteorologic characteristics;

- Dangerous hydrometeorologic processes and phenomena;

- Technogenic changes of hydrologic and climatic conditions or their particular characteristics.

The studies are carried out by collection and analysis of the data on hydrometeorologic and cartographic features of the district, and reconnaissance of the territory and water bodies of the sites.

Engineering-ecological survey. The purpose of the survey is prevention, i.e., to decrease or eliminate unfavorable ecological and other effects, and to ensure optimal living conditions for the inhabitants.

At this stage, the engineering-ecological survey includes:

- Analysis of data on the environment for forecasting;

- Ecological decoding of the aerospace photography materials;

- Geoecological studies during geologic and hydrogeologic survey.

\subsubsection{Scientific research}

The studies will be carried out as outlined below:

- Study of composition, physico-mechanical, filtration, sorption, deformation, thermal and physical properties of common rocks on the site to evaluate site suitability in terms of the enclosing rock mass as a natural barrier;

- Isotope-geochronological studies of closeness of petrologic systems;

- Study of the chemical composition of underground water and dissolved gasses;

- Estimate of solid RW compositions and the reliability of the matrices and containers for disposal in geologic formations;

- Study of interactions at different temperatures and pressures at special test-stands within a system composed of rocks, solidified RW, and underground waters;

- Forecast of tectonic development of the northern part of the Nizhnekansky massif and estimate the influence of active fault dynamics on the hydrologic regime and migration processes;

- Forecast of development of district geomorphologic structures under the effect of exogenic processes;

- Computer modeling of heat and mass transfer processes in the rock massif; 
- Development of structural-tectonic and engineering-geologic models of prospective sites;

The complex engineering survey and scientific research will result in the information and materials to characterize the sites and evaluate the potentials of RW repository subsites, which are required for design decisions.

\subsubsection{Design, ecological assessment, and expert review for JOI}

Design decisions for this stage of the JOI include:

- Preliminary selection of the alternative sites for the underground laboratory and RW repository construction;

- Development of principle layout and design solutions for the underground laboratory and $\mathrm{RW}$ repository facility on the basis of fuller scope geologic and technical-economic assessment;

- Preliminary selection of the equipment for construction and mining operations;

- Specification of the calculated cost of the further design-survey operations, construction of the underground laboratory and complex of scientific studies, and RW repository facility construction;

- Assessment of technogenic impact on the environment of the construction and operation of the future RW repository facility and underground laboratory to ensure conformity with requirements of Regulations about environmental impact assessment in Russian Federation (EIA):

- Development of the program of further design-survey work.

The JOI is developed on the basis of the results of completed surveys, studies, and design decisions. The results received are evaluated by experts and the JOI for the construction of the underground laboratory and RW repository site on the territory of the Nizhnekansky massif must be approved by the Federal authorities and RF Minatom.

The labor required for the JOI stage is estimated to be 365 man years (Table 3 ).

\subsection{Underground Laboratory}

Currently used surface methods of analysis of the earth's crust, including deep drilling, may not yield significant and authentic data either about the interaction of deeply located constructions with enclosing rocks and underground waters or about processes in a system consisting of waste products and engineered barriers in a geologic environment.

The validity of geologic data on rock mass structure and the processes occurring within it, including technogenic factors, can be proved under natural conditions. However, in this case, proof is possible only as a result of implementation of a research program in a special underground laboratory, constructed at the site of the proposed repository.

The main purpose of the underground laboratory is to validate the solutions proposed to the problems of radioactive waste safety and disposal at prospective sites of Nizhnekansky massif. Comprehensive studies conducted in the underground laboratory would obtain detailed information on geologic and hydro-geologic conditions of the construction site, quantitative parameters, host rock isolating properties, and the reliability of engineered barriers. This 
information would allow the evaluation of the RW repository and the repository's impact on the environment.

The implementation of real radioactive waste emplacement in this laboratory should serve as convincing evidence of the reliability and safety of the proposed technical decisions and activities to domestic authorities, public organizations, and the population.

The underground laboratory is designed with two vertical shafts and horizontal drifts. Horizontal drifts may be located at depths of 600 and more meters. Later, the underground drifts at the laboratory may be utilized for emplacement of actual waste products, which would be the first phase of RW commercial repository activities.

The underground laboratory at the JOI stage is not an intricate or unique facility for modern design and driving techniques. The JOI design, which is based on completed studies and appropriate surveys, is sufficient to show that the laboratory's structure, purpose, and technogenic impact on the environment would be minimal during construction and operation. The JOI design for construction also forms the basic stage of the Technical and Economic Justification (TEO) for RW disposal construction.

\subsubsection{Engineering surveys}

Engineering surveys for the underground laboratory draft design, followed by the TEO, should provide acquisition of required materials and data on natural and technogenic conditions for development of design solutions.

These surveys are a basis for construction decisions, design and volume and layout solutions, compilations of situational and general plans of the as-designed facility, development of engineering security, and activities for protection of the natural environment.

Engineering surveys will be carried out in two stages.

Stage I. In Stage I of the surveys, the scale is 1:50000 to 1:25000. The stage I tasks are:

- Obtain more precise knowledge about geological structure and hydrogeological conditions of prospective sites;

- Estimate stress and strained state (SSS) of rocks forming the site;

- Acquire data on filtration characteristics of a geologic section, etc.;

- Select relatively homogeneous engineering and geologic elements of the rock massif at alternative areas;

- Justify underground laboratory site selection.

Comparison of these items will allow justification of the underground laboratory site selection. The following activities shall be carried out for this purpose:

- Specialized geologic or engineering - geologic survey of prospective sites and construction subsites;

- Surface geophysical studies of construction sites, gravimetric and magnetic prospecting, seismic profile shooting and electrical profile prospecting.

Studies on selected sites are: 
- Site geophysical studies (seismicity, gravimetric and magnetic shootings, electrical prospecting);

- Borehole drilling with core sampling, a complex of geophysical methods, detailed testfiltration works (pump down, injections) of the overburden section. There will be approximately 5 or 6 boreholes, $1000-1500 \mathrm{~m}$ deep, and 10-15 boreholes, $300 \mathrm{~m}$ depth

- Hydrogeological and radiation surveys of repository prospective sites and subsite;

- Microseismic zoning of prospective sites;

- Geodynamic studies;

- Engineering-geodetic works;

- Engineering-ecological surveys for working out section "Environmental protection".

- Hydrometeorological investigations at construction sites and alternative subsites.

Stage II. Engineering surveys of stage II will be carried out on a scale of 1:10000 - 1:5000 to study geological structure and hydrogeological conditions of the construction site and underground laboratory, and to forecast the interaction of underground facilities with the rock massif. Primary tasks are the following:

- Detail the subsite geological structure;

- Define a spatial location of filtering faults in water-tight rock blocks;

- Estimate increased stresses and rock mass off-loading effect on hydrogeological regime, rock state and properties;

- Forecast estimates of mining-geologic conditions of underground complex construction and operation;

- Study, with greater precision, geologic and hydrogeological processes to justify RW disposal safety.

After completing these primary tasks in Stage II, additional work is planned to study rock mass state and properties directly in the proposed construction area. These tasks include:

- Engineering-geological survey;

- Geophysical studies (site seismic prospecting, magnetic prospecting, and electrical prospecting on separate sites of the massif);

- Hydrogeological and radiation surveys;

- Engineering and geodetic works;

- Boreholes drilled 800-1200 $\mathrm{m}$ deep where a complex of studies will be performed to specify geologic and hydrogeological conditions of the construction site, and define a location for the underground laboratory. The minimum number of boreholes planned is three;

- Seismo-acoustic gamma-ray test of rock massif to specify data on structural and deformation characteristics of rock massif all along the site;

- Microseismic zoning of a site with detailed calculation of the effect of seismic parameters for construction of underground structures;

- Geodynamic studies on special polygon; 
- Estimate of environmental conditions prior to the beginning of facility construction;

- Proposals for the program of ecological monitoring.

\subsubsection{Scientific research}

Stages I and $I I$ of the engineering surveys and scientific research involve:

- Forecast of variations of hydrogeological conditions in the RW disposal during the period of ecological hazard;

- Definition of physical-mechanical, petrological, and geochemical properties of rocks composing the area;

- Study of protective (isolating) rock properties at individual sites obtained from borehole drilling and testing;

- Study of sorption properties of rocks and minerals in relation to major radionuclides;

- Tests of radionuclide leaching from matrices by underground water;

- Engineering-geologic simulation of disposal conditions and heat and mass transfer processes;

- Development of mathematical models of radionuclide migration with reference to actual conditions of the massif under study;

- Age determination of underground water at prospective sites by isotope geochronology;

- Study of rock stress and strain state on construction areas;

- Estimate of seismic effect on underground facilities;

- Analyses of chemical composition of underground water and gasses dissolved in water.

\subsubsection{Working design for underground laboratory construction}

The approach to construction of the underground laboratory at the working design phase includes:

- Detailed study of surface facilities layout;

- Location and depth of underground laboratory drifts;

- Study of shafts and drift structures;

- Mechanization and procedures for making excavations in the rock;

- Activities ensuring work safety during construction;

- Equipment for performing scientific studies in the underground laboratory;

- Activities for development of geomonitoring system;

- Estimated cost calculations for underground laboratory construction and operation.

The development of the working design for the underground laboratory will be carried out on the basis of completed studies.

The results of completed engineering-geologic and design works undergo state expert examination for completeness, quality, and authenticity of the data for laboratory construction and environmental protection. 


\subsubsection{Underground laboratory construction}

The program of engineering surveys during laboratory construction specifies the minimum number of prospecting drifts for performing research work, revision of the design solutions and their engineering-geologic justification. Design solutions include drilling, geologic and hydrogeologic studies while driving shafts and drifts.

Drilling. Two boreholes of up to $1000 \mathrm{~m}$ deep will be drilled with continuous coring to choose the location of shafts and evaluate geological conditions for future excavations. Boreholes will be tested during driving.

The complex of test-filtration works, logging, pressiometry, seismoacoustic studies, assessments of rock massif stress and strain state (SSS) and geothermal conditions will be performed. Borehole drilling will be followed by sampling and laboratory analysis of physical-mechanical rock properties and the chemical composition of underground water.

\section{The organization of geomonitoring system}

The geomonitoring system includes surface and underground observations. Surface hydrological studies of the regime of constant water-flows and reservoirs at the area will be carried out. Hydrometeorological observations are conducted at special posts. The prospecting boreholes drilled earlier will be re-equipped to observe the underground water regime. Geodynamic processes will be studied at special polygons.

Ecosystems will be observed and their resistance to technogenic impacts and their ability to recover will be defined. A system of underground geomonitoring will be implemented during laboratory construction. The order and organization of various observations will be tested and revised.

To predict possible failures and emergencies while excavating and for their timely prevention, drift conditions will be evaluated by mining -engineering safety criteria; and precautions, remedies, and remediation activities delineated.

\section{Engineering-geologic studies}

Detailed mapping of rock massif overburden rock, including tectonic disturbances, individual fractures, and zones of water manifestation will be carried out during drilling of shafts 600-700 $\mathrm{m}$ deep and horizontal drifts.

Water inflows into drifts will be measured and samples will be taken of water and rocks for laboratory studies.

Prospecting boreholes drilled out from drifts will be used for test-filtration, logging, seismoacoustic and pressiometry work to solve various problems of engineering-geologic justification of technical and organizational activities while updating the design.

The results of engineering-geologic investigations in drifts serve as executive documentation for geosupervision.

\subsubsection{Scientific research and experimental work in the underground laboratory}

Research and development and experimental work planned for the underground laboratory include: 
- Detailed studies to prove the selected area conforms to requirements for safe and secure RW isolation;

- Experiments to study engineering loading impact on the rock massif and engineered barriers;

- Experiments on modification of civil work technology and safe radioactive waste management in underground conditions.

The studies to assess the conformity of the selected area chiefly include detailed analyses of geological structure and hydrogeological, geodynamic, geomechanical, thermal and other processes. The findings as to the suitability of the rock massif as an isolating environment will determine the area, depth, and orientation of drifts for future RW disposal.

The purpose of experimental research on analysis of the impact of technogenic burden on the rock massif is to study the formation of thermal fields around heat sources, and their effect on the filtration and isolating properties of the rocks.

Experiments to modify our understanding of underground facility construction and safe radioactive waste management will be carried out in order to:

- Obtain approval of the JOI by federal government bodies;

- Improve driving technique and drift supports, and to isolate various water transmissible failures;

- Develop engineering means of waste delivery, overloading and transport in the underground repository;

- Modify the technique of loading and isolation of RW waste packages in special drifts and boreholes;

- Conduct geomigration studies on: the course and filtration rate in water-saturated zones to define rock sorption properties under natural condition at the level of major facility locations;

- Study physical and chemical processes followed by RW disposal, including experiments in a disposal environment system of solidified RW simulators and isolating materials.

When the research is completed, state experts review the results of host rock massif studies. Then, after obtaining data demonstrating suitability of the selected subsite for RW isolation and expert approval of the results of completed experiments, we will develop the Technical and Economic Justification (TEO) for construction of the solidified RW repository facility.

\subsection{Development of TEO for Construction of the RW Repository Site}

Engineering surveys performed during development of the working documentation for the underground laboratory, geological and geophysical and hydrogeological studies completed during construction and operation, and the results of comprehensive R\&D work carried out in underground conditions form the background for development of the TEO for RW repository construction.

In addition, we will carry out surveys to support design decisions for the RW repository project and develop measures for environmental protection. 


\subsubsection{Engineering surveys for TEO development}

Engineering surveys and design and construction work aimed at TEO development are similar to surveys executed for the JOI and the working documentation for underground laboratory construction $(2.3 .1,2.4 .1)$; however, the level of detail is higher. Engineering surveys will be carried out on a scale of 1:5000-1:2000. These include:

- Analysis of the results of completed studies;

- Engineering-geological survey;

- Site geophysical studies (seismic prospecting, magnetic prospecting, electric prospecting);

- Geodetic work;

- Hydrogeological and radiation surveys of individual portions of subsites for future construction;

- Boreholes of 800-1200 m and 150-300 m deep for detailing geological structure and rock massif hydrogeological conditions within the boundaries of the RW underground storage and buffer zone, and also to justify the location of drifts will be drilled. The complex of studies in boreholes is similar to that described in item 2.3.1. In addition, seismic $\mathrm{x}$-ray examinations will be made. There will be a minimum of six boreholes, $800-1200 \mathrm{~m}$ deep, and ten to twelve boreholes up to $300 \mathrm{~m}$ deep.

- Studies on geodynamic polygons;

- Specification of hydrometeorological conditions on the construction site;

- Seismological observations.

Further engineering-ecological surveys to be carried out include:

- Specification of the limits of technogenic impact of the future repository on major ecosystem components;

- Reception of parameters required for predicting the behavior of the natural environment in a zone affected by the construction and operation of the facility;

\subsubsection{Scientific and research work}

The main studies will be carried out in the underground laboratory. The results will serve as a basis for design and construction works on RW repository construction.

Isolating rock properties, including sorption properties in relation to major radionuclides, are studied from core materials obtained while drilling. Actual and estimated physical and mechanical host rock performance will be assessed.

The three-dimensional mathematical model of engineering-geological conditions is designed for near and distant field of the RW repository.

Additional calculations will be made of solidified RW compositions and their possible allowable heat release with reference to real geological conditions, and then the matrix materials will be selected. We will also make a long-term forecast of climate variations, geomorphology, geological conditions, and hydrogeology of construction subsites. The concept of RW isolation will guide the comprehensive analysis and safety estimates of the future repository. 


\subsubsection{TEO development}

Design and construction decisions for the RW repository are based to a considerable degree on the results of studies performed in the underground laboratory. They include:

- Detailed studies on layout of surface and underground facilities;

- RW management procedure from delivery and loading into special drifts until closure of the disposal;

- Elaboration of isolating and protective structures to ensure radiation safety during the disposal operation;

- Technical equipment for the processes;

- Calculation of construction and filling materials;

- Development of measures for protecting designed constructions from underground water during construction and operation;

- Recommendations for natural resources management, and, also, on rehabilitation and improvement of the natural environment;

- Specification of cost estimates for facility construction and operation.

Results of the TEO will be considered by the state supervising organizations and will be subject to ecological examination. TEO approval and decisions on repository construction are made upon positive results from the expert review.

Labor for the TEO stage is estimated at 562 man years (Table 3).

\subsection{Development of Working Documentation for Repository Construction}

\subsubsection{Engineering surveys}

Engineering surveys for development of the Working Documentation (WD) are aimed at detailing the conditions of interaction of $\mathrm{RW}$ repositories with host rocks and the environment. They should provide data required for calculations of surface buildings and underground structures. This should also include data for engineering security and for specification of design decisions for individual issues raised during TEO development.

Engineering surveys at this stage will be carried out on a scale of 1:2000 to 1:1000 and will include:

- Engineering-geological survey for building;

- Geodetic studies for compiling the master plan of surface underground facilities;

- Surface geophysical studies of individual parts of the subsite (i.e., seismic prospecting, electrical prospecting) will be carried out, if necessary;

- Six or more boreholes drilled with continuous coring and a full complex of geologicgeophysical and hydrogeological studies. Borehole depth is specified by position in the rock massif of the repository, and horizontal coordinates by the area of future construction;

- Geodynamic studies on special polygons; 
- Laboratory studies.

Scope and type of these studies will be determined by the results of previously completed design and construction work.

\subsubsection{Scientific support for Working Design}

Scientific support for the working documentation will include a wide spectrum of studies:

- Detailed modeling of engineering-geological conditions at the construction site;

- Laboratory and in-situ studies and experiments;

- Development of computer model for hydrogeochemical radionuclide transfer from RW repository within mining field;

- Forecast scenarios for development of natural and technogenic events during repository loading and after closure;

- Development of geomechanical model of interaction of underground facility with host rock massif;

- Forecast of RW repository state for the preset period of time;

- Probability analysis of RW safe disposal;

- Estimate of repository technogenic impact on the environment.

\subsubsection{Development of Working Design for construction}

This stage includes design and construction decisions, and environmental protection issues. Work will focus on a detailed study of the design documentation.

Detailed drawings will be made, including unit detail drawings of surface and underground facility structures, as well as service lines, power lines, roads, etc., and their general parameters will be defined in the approved TEO. Final values will be established for the depth of contour intervals and layout scheme of the repository.

The complete list of required technical means and equipment for work implementation and operation of surface and underground complexes is prepared.

Methods and procedures of civil engineering and installation works and driving technique and, also, activities aimed at their safe execution will be elaborated.

The final cost of repository construction is established.

The effect of construction on natural environment (soils, vegetation, space, water resources) will be assessed. Activities for environmental protection and its rehabilitation will be confirmed.

The total labor effort for design, survey, and construction work at the WD stage is 634 man years (Table 3).

\subsection{Construction, Operation, and Closure of the RW Repository}

A preliminary schedule for construction and operation of the RW repository is given in Table 4 . 


\subsubsection{RW repository construction}

RW repository construction consists in building surface premises for various uses, and the driving and arrangement of drifts. Operations include:

- Lay access roads, service lines, and the surface production area, and construct underground, offices and industrial buildings and structures;

- Expand geodetic polygon within the limits of the allotment to register possible geodynamic activity of structural-tectonic blocks of the rock massif. The network of boreholes to observe the regime of underground water can be extended, if necessary. Existing boreholes can be used for this purpose or new boreholes can be drilled.

- Drill boreholes to be used as shafts, perform core sampling and a full complex of geologicgeophysical and hydrogeological studies. Sinking of the shaft collars includes the following: (a) Drive, support, and reinforce vertical shafts for projected depth, layout pit-bottom drifts with a permanent support and (b) Drive transport and operational horizontal drifts with a permanent support. Conduct civil and installation works to install engineering equipment in vertical and horizontal drifts;

- Preparation work for geomonitoring.

\section{Engineering surveys and scientific research}

Engineering-geologic surveys performed during building, operation, and liquidation of the RW repository should provide the required materials and data on the state and variations of individual constituents of the geologic environment in the facility area. Surveys are carried out in order to increase the reliability and operational suitability of both the surface and underground complex of facilities, safety of operations, protection of the environment and human health.

Surveys performed during facility construction help to establish conformity of the engineeringgeological conditions, as approved in the design documentation, to actual conditions on the basis of engineering and geologic examinations in drifts, the study of dynamics of stress and strained state (SSS) in supports and enclosing massif, and geomonitoring data.

Surveying and engineering-geologic operations are carried out while driving shafts and horizontal drifts; they document geologic specifications of the rock, and describe tectonic disturbances.

Other activities include mapping and photographs of geologic and structural-tectonic heterogeneities, sampling rocks and underground water, drawing up detailed sections and executive maps, and documenting water ingress into drifts.

Engineering conditions of rocks and supports and zones of water-manifestations will be examined by recording emission acoustic and electromagnetic impulses along the full length of horizontal drifts. Geomonitoring observation posts are also planned.

The geomonitoring system was designed from results of technical tool examination and the executive geologic-surveying documentation. It is designed to make observations over time of the geomechanical, hydrogeological, radiation, thermal, physical, and geochemical processes in drifts and the enclosing rock massif. 
Table 3. Summary of labor effort during design, survey, and construction at the Nizhnekansky rock massif.,

\begin{tabular}{|c|c|c|c|c|}
\hline & \multicolumn{4}{|c|}{ Labor effort, man year } \\
\hline Types of prospecting and research works & DOI & JOI & TEO & WD \\
\hline 1. Analysis of the results of previously completed studies & 20 & 10 & 10 & 5 \\
\hline 2. Geologic and engineering-geologic works & 10 & 20 & 16 & 12 \\
\hline 3. Drilling & & & & \\
\hline - drill teams & - & 121 & 180 & 140 \\
\hline - geologic-geophysical and hydrogeologic support of works & - & 12 & 20 & 20 \\
\hline 4. Seismic and microseismic zoning & 2 & 3 & 3 & - \\
\hline 5. Surface geophysical studies & 8 & 16 & 20 & 12 \\
\hline 6. Hydrogeologic and radiation surveys & - & 8 & 6 & - \\
\hline 7. Engineering and geodetic operations & 2 & 6 & 5 & 5 \\
\hline 8. Engineering and ecological surveys & 2 & 4 & 5 & 2 \\
\hline 9. Studies of rock mass conditions and properties & - & 4 & 6 & 4 \\
\hline 10. Engineering and hydrometeorological surveys & - & 4 & 3 & 1 \\
\hline 11. Lab-scale studies & 5 & 20 & 30 & 20 \\
\hline 12. Scientific support (mathematical modeling, forecast, etc.) & 20 & 40 & $50^{*}$ & 30 \\
\hline 13. Development of design decisions and documentation & 15 & $76^{\star}$ & $190^{\star}$ & $380^{*}$ \\
\hline 14. Expert's review and approval of the design documentation & $8^{\mathrm{c}}$ & $15^{\mathrm{c}}$ & 15 & - \\
\hline 15. Surface geomonitoring & - & - & 3 & 3 \\
\hline Total & 92 & 365 & 562 & 634 \\
\hline
\end{tabular}

"The given labor effort for prospecting and drilling (item 4-13) is used for analysis of territory of category 1. Territory of Nizhnekansky massif is referred to category III. In this connection total labor effort of operations for these operations may be increased.

${ }^{b}$ Capital costs will be evaluated at JOI stage.

'Quantitative estimations of labor effort of research and development and design and exploration works will be revised. 
If there are any discrepancies between actual engineering-geological conditions and those in the project approval, the design decisions would be revised, and recommendations for driving procedure and methods given, including the technology of drift support, and preventive and protection measures.

The choice of places for RW emplacement in drifts will be made based on results of completed studies. Models of storage conditions and the system comprising waste-engineered barriers and the rock massif are final; they form the basis for technological decisions for RW storage.

\subsubsection{RW repository operation}

Repository operation involves multiple technical activities, part of which are described below:

- Deliver waste packages and containers with RW from surface into underground structures;

- Load containers into drifts with subsequent packing of cavities with bentonite clay and building concrete partitions between them;

- Load waste packages into boreholes with periodic packing of cavities with bentonite clay;

- Drill boreholes for waste packages to enlarge RW emplacement area;

- Geomonitoring via a network of observation posts (boreholes, posts, points) that was created at previous stages of surveys.

The results of the study present data regarding the agreement of the preliminary forecasts to actual variations of engineering-geological conditions for the period of operation of the underground structures. The assessment is made, tendencies toward further variations are defined and causes described. Recommendations are given on how to eliminate the adverse affects on drift stability, change technological processes and regime of operation, and modify methods of engineering security.

\subsubsection{Permanent closure of RW repository}

When the repository is full, a final packing of all horizontal drifts with bentonite will be done and shafts closed with bentonite seals.

Engineering surveys performed during liquidation of RW repository will focus on revealing contaminating substances in the geologic environment that are dangerous to population health. Methods to utilize and neutralize these materials will be developed; soil cover is analyzed and recommendations made for replacement of ground and soils on individual sites of the territory. The assessment of environment conditions is made as a result of the specialized examination of the territory, analysis of underground waters in observation boreholes, surface reservoirs and in water inlets. A plan of activities for revegetation of the RW repository site is to be created and implemented. 


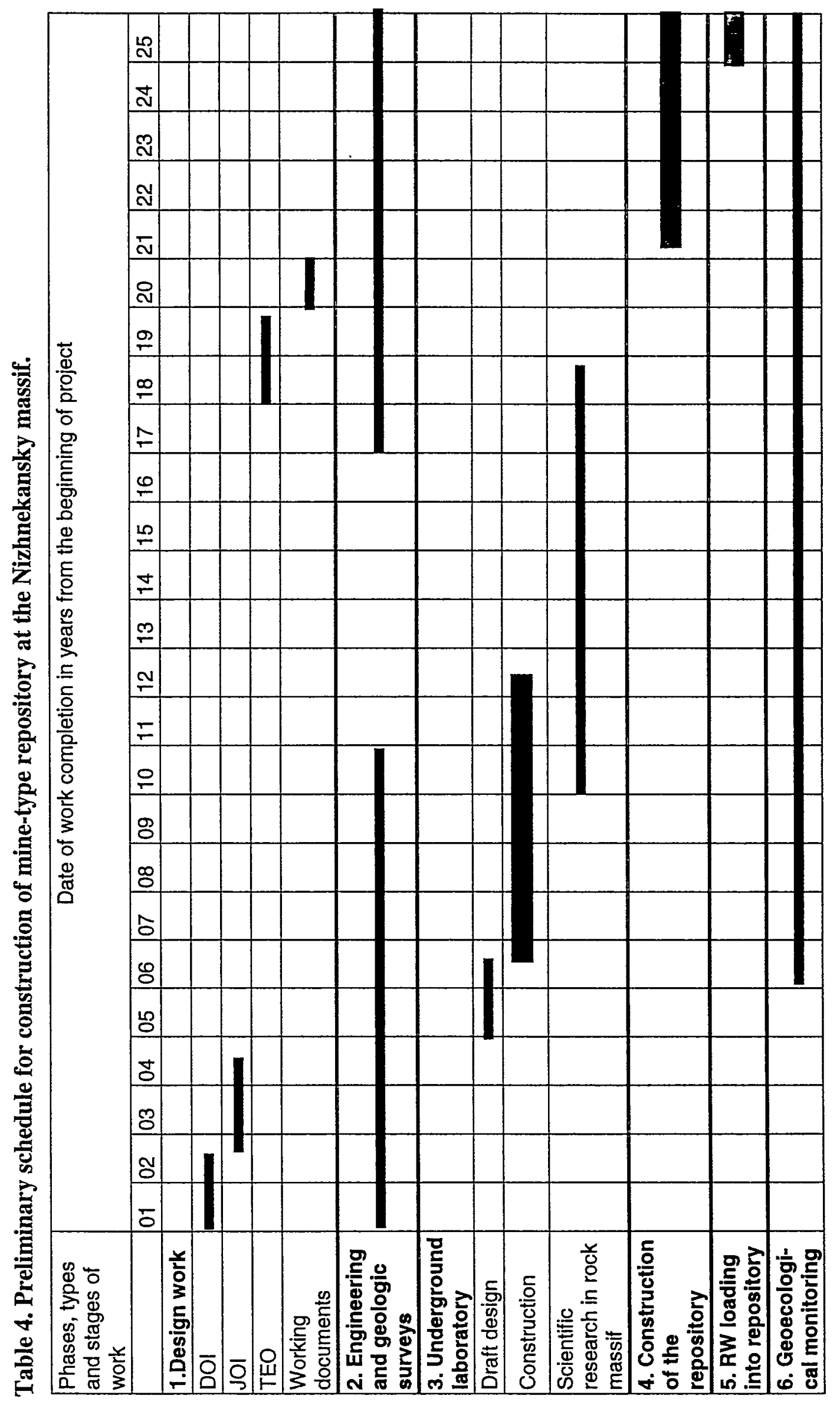




\section{CHAPTER 3. DESIGN AND EXPLORATION WORK IN THE BUFFER ZONE OF PA "MAYAK"}

\subsection{Status of Prospective Sites for an RW Repository at PA "Mayak"}

VNIPIpromtehnologii (VNIPIPT) has conducted comprehensive research on the prospects of underground repository construction both within the combine site and in adjacent areas since the 1970 s, when the problem of radioactive waste isolation became urgent.

As a result, complexes of metamorphic and igneous rocks and several intrusive rock massifs were defined as potentially suitable for final disposal of radioactive waste. However due to social, technical, and economic considerations, the major prospects for construction appear to be associated with the buffer zone at Mayak.

Based on the completed studies, the area northeast of Karachai Lake (Mars-2 or M-2) was chosen as the site for constructing an underground laboratory for studying RW disposal processes. The subsequent use of Mars- 2 as the site of the RW disposal facility was also considered (Fig. 9). A network of boreholes was arranged within the site, drilled to depth of 300 $\mathrm{m}$ to $1200 \mathrm{~m}$. A total of 21 boreholes were drilled with a total length of over $10000 \mathrm{~m}$. Filtration tests were carried out during drilling and thereafter, together with a complex of geophysical surveillance observations in the boreholes and surface geophysical studies.

Based on these studies, the geological structure, rock mass structure, and hydrogeological characteristics of the site have been defined. At the surface is a Meso-Cenozoic weathering crust consisting of loam, interlayered with ground with rock debris, gradually changing over into intensely fractured zones, then into monolithic ones. Native sediments are formed from a rock complex of Silurian-Devonian age; they appear to the depth explored $(1200 \mathrm{~m})$ with intermittent layers of lava breccias and welded tuff porphyrites.

The filtration properties and hydrogeologic features of the rock mass have a direct relationship to the extent of fracturing. A major aquifer spreads in the upper part of the rock mass up to a depth of $100 \mathrm{~m}$. Only single zones are permeable below this level and, at depths of $400 \mathrm{~m}$ have filtration coefficients not exceeding $510^{-3} \mathrm{~m} /$ day.

In the early 1990s, studies of the rock mass within the combine's buffer zone were carried out by the institute IGEM RAN, geophysical laboratories of Ekaterinburg, and other entities. The result was a detailed characterization of the geological structure of this area. Studies of petrological composition and geochemical properties were also made. Based on these results and, primarily, on the data from geological mapping, IGEM experts selected three more sites for construction of the RW repository (sites I, II, III) (Fig. 9).

In the mid-1990s, using data from long-range studies performed by FGU NPP "Aerogeologia" and VNIPIPT, one more site, No IV, was selected to the south of the Techa river (Fig. 9).

The structure was investigated at depth only for site M-2, and it is, naturally, insufficient to make any final conclusion about the prospects of these sites in terms of their suitability for RW underground storage. 


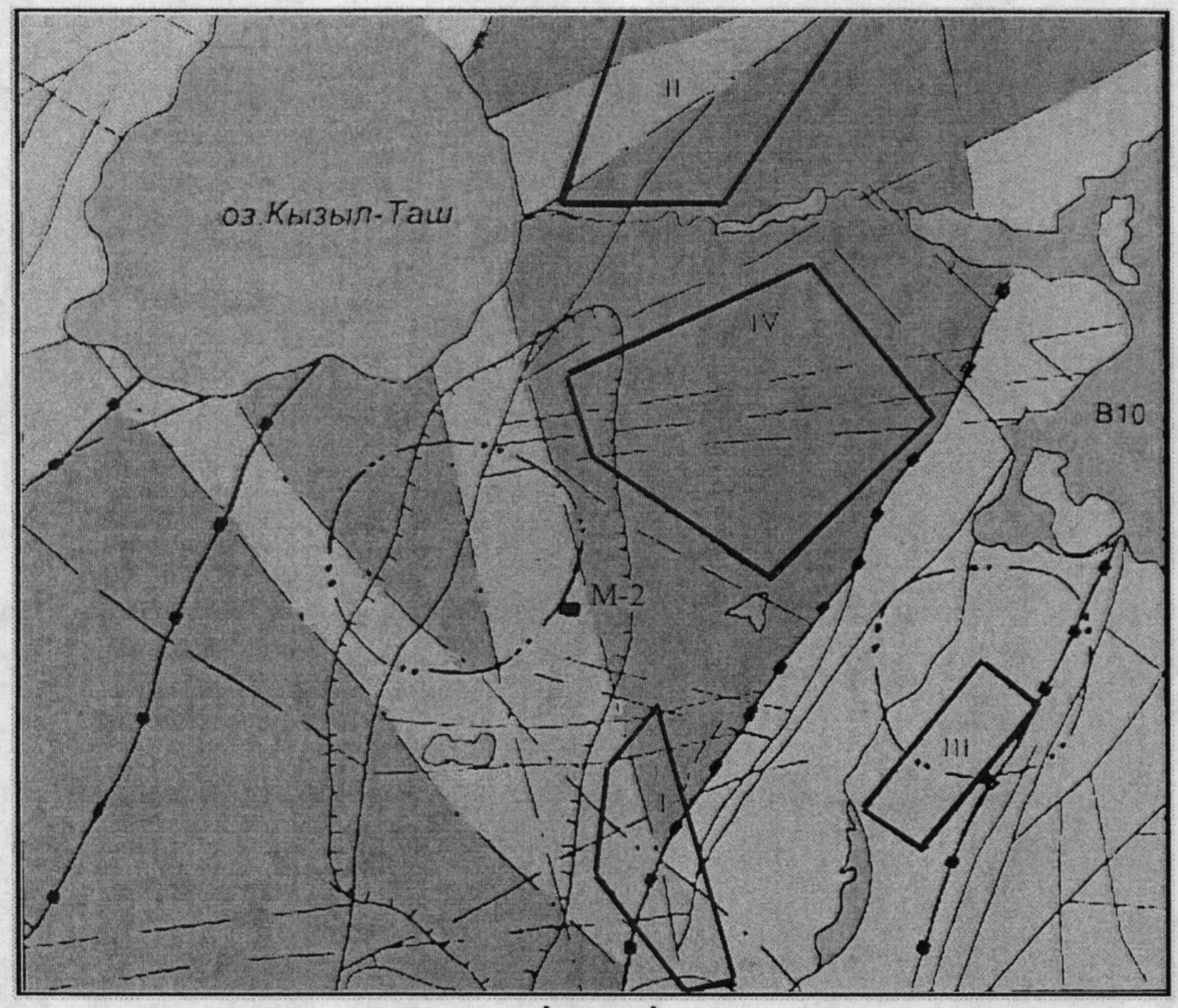

Legend

$\begin{array}{lll}\text { Regional breaks } & \text { Phipped breaks of all-Ural range } \\ \text { Aureole of underground waters } \\ \text { pollution }\end{array}$

Fig. 9. Promising sites for RW geological repositories at PA "Mayak". 
The analysis of geologic and hydrogeological conditions of the environment and existing buildings in the area of the buffer zone, performed by VNIPIPT experts, shows that sites M-2 and II can be regarded as the most suitable for construction of the RW repository (Fig. 9).

A soundly substantiated evaluation of the prospects for construction of an RW disposal at a selected site would be possible only after engineering surveys, deep exploratory drilling, and design works carried out according to special programs developed by VNIPIPT. Thus, the final decision on solidified RW storage can be made only after construction of the underground laboratory and a complex of scientific research has been performed there.

Because of contamination of underground waters with radioactive waste from Karachai Lake at site M-2 (later referred to as Central), the underground laboratory and RW disposal can be constructed only as a borehole type structure; while at site II (Severnji) it is possible to use both borehole and shaft type structures.

Because shaft type construction was considered in the previous sections, only the main elements of construction for a borehole repository is described below.

\subsection{Development of the Declaration of Intent}

The area of the buffer zone at PA "Mayak" is characterized by a high degree of knowledge of its hydrogeology. To assess the extent of radionuclide contamination of waters in surface reservoirs and the upper aquifer, a large number of boreholes up to $100 \mathrm{~m}$ in depth have been drilled. Due to industrial buildings and structures located in buffer zone, the area has been described by geodetic materials also. Hydrometeorological and hydrogeological observations are constantly carried out, and ecological monitoring is being performed.

This information allows us to considerably reduce the scope of engineering surveys, and, accordingly, to reduce expenses to assess the feasibility of safe RW isolation at the proposed Mayak sites.

\subsubsection{Main types of survey and research work}

The goals and tasks of surveys and scientific support for development of DOI are similar to planned activities in item 2.2.1. However, the area that geologic and geophysical and hydrogeological studies must cover is considerably smaller, $100-120 \mathrm{~km}^{2}$ compared to $1500 \mathrm{~km}^{2}$ at the Nizhnekansky site.

The assessment of ecological conditions and radionuclide contamination of investigated territory is given in terms of feasibility of RW disposal construction. Sources of the input data include information from the special services of PA "Mayak", results of engineering-ecological studies of previous years, and radiation surveys.

The materials describing the principal characteristics of the area of facility construction, similar to item 2.2.1, should be obtained from previous studies.

The principal characteristics of the area serve as a basis for:

- Justification of the size of sites for further investigations;

- Planning possible construction subsites with regard to radioactive contamination of the construction area and its buildings; 
- Preliminary forecast of potential changes in the environment and its components.

\subsubsection{Development of DOI}

The design and construction tasks at this stage are similar to those stated in item 2.2.2. This stage includes design solutions and expert review of the material covering the creation of the RW repository and underground laboratory as listed below:

- Define operating conditions in the areas contaminated with radioactive substances;

- Develop pre-design decisions for an RW disposal of the borehole type;

- Develop tentative construction details for a borehole underground laboratory;

- Make extensive assessment of ecological safety of RW underground isolation in the repository of borehole type;

- Estimate the rough cost of construction of underground laboratories and future RW repositories of the borehole type for each site.

Based on the investigations conducted, the DOI for construction of an RW storage site in the buffer zone of PA "Mayak" is prepared. Then the expert conclusion must be compiled, the DOI confirmed by the local authorities, and, finally, the DOI approved by RF Minatom.

The estimated labor efforts for the DOI stage amount to 76 man years (Table 5).

\subsection{Development of the JOI for RW Repository of the Borehole Type}

The goals and tasks of engineering surveys, scientific research, and design and construction work for developing the JOI are stated in item 2.3.1.

\subsubsection{Engineering surveys}

The engineering surveys at this and subsequent stages suppose completion of a complex of studies similar to that stated in item 2.3.1. However, the scope of work is smaller, covering up to $80-100 \mathrm{~km}^{2}$.

\section{Engineering-geodetic surveys}

Engineering-geodetic surveys at the JOI stage include the same kinds of work as in item 2.3.1. Operations are conducted on a scale of 1:50000 to $1: 25000$.

\section{Engineering-geologic surveys}

The goals, tasks, and content of engineering-geological examinations are mostly similar to those in item 2.3.1. The differences are stated below:

- Gamma survey of prospective sites;

- Hydrogeological and radiation survey at Severnji site, and an radiation survey at Central site (M-2);

- Drilling one to three exploration boreholes, 1000-1500 m deep, and three to six boreholes, 200-300 m deep, at each site. All boreholes are drilled with core sampling, accompanied by the whole complex of geologic, geophysical, and hydrogeological studies. The borehole locations are defined from the results of geologic-geophysical investigations. 


\section{Engineering-hydrometeorological surveys}

Surveys solve the same tasks as stated in item 2.3.1.

\section{Engineering-ecological surveys}

Engineering-ecological surveys at the JOI stage consist of:

- Collection, processing, and analysis of the published and stock materials and the data on environment conditions, buffer zone and the extent of buffer-zone contamination with radioactive substances;

- Geoecological studies during geologic or hydrogeological surveys.

\subsubsection{Scientific and laboratory studies}

Studies include:

- Petrographic analysis of core material;

- Analysis of composition and physical-mechanical properties of rocks, and chemical composition of underground waters and dissolved gases;

- Analysis of composition of contaminated waters, migrating from Karachai Lake;

- Study of physical-mechanical, geochemical, and sorption properties of sample rocks;

- Isotope geochronology studies of the extent of closeness of petrological systems;

- Estimates of solid RW compositions and reliability of matrices and containers to be emplaced in boreholes;

- Analysis of interactions in the system composed of the rock mass, solidified RW, and underground water at various temperatures and pressures at special test stands;

- Computer modeling of the processes by which RW moves through rock-mass fracturing zones, using data on radionuclide migration in underground waters of the PA "Mayak" buffer zone.

\subsubsection{Preparation of JOI}

\section{Initial data for JOI}

Comprehensive engineering surveys result in selection of the alternative sites for future labs and RW disposals. Surveys will be carried out similarly to item 2.3.3.

\section{Design decisions. Development and examination of JOI}

At the JOI stage, design and construction work includes:

- Prepare the initial data, engineering surveys, and scientific research to design the construction of sites and subsites of the planned facility;

- Develop key layout and design decisions for the underground laboratory and RW disposal of the borehole type on the basis of extensive technical and economic estimates;

- Make a preliminary choice of equipment for civil construction work and for drilling boreholes of the required diameter;

- Plan safety measures for operations in the contaminated area; 
- Assess technogenic impact of construction and operation of the underground laboratory and RW disposal on the environment according to normative documents (EIA);

- Create the program for future design and exploration work;

- Specify estimated cost for further design and exploration work, construction of the underground laboratory, and comprehensive scientific research and construction of the RW disposal.

The results obtained are evaluated by experts and the JOI for the underground laboratory and RW storage site on the territory of PA "Mayak" is approved by the Federal authorities and RF Minatom.

The estimated labor consumption for the JOI is 327 man years (Table 5).

\subsection{Underground Borehole Laboratory}

Construction requirements for a laboratory of the borehole type in the buffer zone of PA "Mayak" are similar to those for the underground laboratory at the Nizhnekansky massif (item 2.4).

The choice of location and construction of the laboratory are defined by the tasks listed in 2.4, and the planned investigations should provide the necessary information to resolve key issues.

The laboratory itself will be a cluster of technological and observation boreholes drilled at depths of $450 \mathrm{~m}$ up to $1000 \mathrm{~m}$ spaced 5 to $20 \mathrm{~m}$ apart.

The complexity of geological and hydrogeological conditions of the igneous sedimentary rock complex comprising the PA "Mayak" buffer zone needs to be taken into account. Consequently, the underground laboratory may be set up as clusters of one to three boreholes arranged within the limits of prospective construction sụbsites.

\subsubsection{Engineering surveys}

The goals and tasks of engineering surveys for developing the draft designs are given in 2.4.1. The work will be carried out in two stages:

\section{Stage I}

Stage I involves the choice and justification of a construction subsite for the underground laboratory. Surveys to a scale of 1:25000 to 1:10000 and larger will be carried out for this purpose at each alternative site; they will include:

- Specialized geologic or engineering-geologic surveys;

- Surface geophysical studies of construction areas (gravimetic and magnetic prospecting, seismic- and electro-profiles prospecting);

- Boreholes drilled at alternative sites with core sampling, accompanied by the full complex of geophysics methods, detailed geologic, hydrogeological and hydrodynamical investigations in the excavated sections;

- Hydrogeological and radiation surveys;

- Microseismic zoning; 
- Geodynamic studies;

- Engineering-geodetic surveys;

- Specialized geoecological surveys to assess radiation safety during work in the construction subsite and to acquire the additional information necessary for the section on Environmental protection;

- Engineering-hydrometeorological studies executed at special stations and posts of PA "Mayak".

The work at stage I should determine the final selection of the area for the construction of the underground laboratory.

\section{Stage II}

Stage II of the surveys will study geologic and hydrogeological conditions of the construction subsite, and the optimal layout of the underground laboratory and RW repository of the borehole type. Engineering surveys will be carried out on a scale of 1:10000-1:5000 and larger. They include:

- Engineering-geological survey;

- Surface geophysical studies (seismic prospecting, magnetic prospecting, and electroprospecting at individual sites of the rock massif);

- Radiation survey of separate parts of the construction subsite;

- Engineering-geodetic operations;

- Completion of not less than 3 boreholes of 800-1200 m and 5-6 boreholes of 150-300 m deep, accompanied with a full complex of studies;

- Seismoacoustic gamma-ray test of rock massif;

- Microseismic zoning of construction subsite;

- Geodynamic studies on special polygons;

- Gamma survey of the construction subsite.

\subsubsection{Scientific studies at stages I and II}

Similar to those stated in item 2.4.2.

\subsubsection{Draft design of underground laboratory}

Construction and design decisions for the underground laboratory at the draft design stage include:

- Detailed studies on layout of surface complex of facilities;

- Define the location and depth of technological and observation boreholes for the underground laboratory;

- Develop borehole structure for scientific research;

- Choose equipment and machinery for drilling; 
- Develop measures to ensure safety of operations during construction in areas contaminated with radionuclides;

- Equip underground laboratory for researches;

- Develop measures aimed at creation of geomonitoring system;

- Calculate estimated cost of construction and operation of underground laboratory;

- Perform activity on environmental protection.

Based on the completed studies, the draft design of the underground laboratory is being elaborated. Then the state expert examination will be conducted regarding the engineering surveys, including completeness, quality and reliability of the data for building the laboratory, and ensuring environment protection. After the state expert's appraisal of the draft design and its approval, construction of the underground laboratory will begin.

\subsubsection{Construction of the underground laboratory}

The main kinds of geologic and geophysical studies to be done during underground laboratory construction are associated with drilling technological and observation boreholes.

One of the major tasks is to analyze the processes of migration of leaching products from the $\mathrm{RW}$ repository. Therefore, technological and observation boreholes will be arranged in accordance with the most probable direction of underground water flow in zones of intense rock fracturing.

The complex of test-filtration, logging, pressiometry work, and seismoacoustic studies is executed in these boreholes. Analysis of the stressed-strained state of the rock massif and its geothermal conditions will be carried out. Borehole drilling is accompanied by sampling and laboratory studies of physical-mechanical and geochemical properties of rocks and the chemical composition of underground waters etc. Seismoacoustic-ray tests will be carried out.

The geological structure and the extent of disturbance of the massif laid bare by boreholes of the underground laboratory will be studied in detail. We will establish the composition and properties of the rock mass; and the sizes, location, and filtration parameters of both waterpermeable zones and individual fractures. These data form the basis for engineering-geologic and migration models.

Studies on geodynamic polygons are in process, and we will observe the impact on the environment during building surface facilities and borehole drilling for the underground laboratory.

\subsection{Scientific Studies in the Underground Laboratory}

Research will be conducted in the underground laboratory to assess the conformity of the selected construction subsite to the requirements for safe and reliable RW storage. They include:

- Experiments to study variations of natural and engineered barriers under the effects of natural and technogenic factors;

- Studies of changes in the radiation levels during work with simulated or real RW in the technological and observation boreholes to define the radioactivity range in time and its extent within the rock massif; 
- Hydrogeochemical and geomigratory studies. The results will define the actual underground water flow rates in various fracture zones. We will also study processes of radioactive isotope migration with underground water under actual mining and geological conditions, and sorption properties of rocks in relation to individual isotopes;

- Analysis of rock mass temperature regime in the area of the borehole repository with the help of artificial heat sources;

- Perfection of the process for loading waste packages into the technological borehole;

- Studies of physical and chemical processes during RW storage in the borehole to bring to light any possible variations of physical-chemical and physical-mechanical properties of the environment in the waste package/borehole/rock mass/liquid phase system.

Investigations carried out in the underground laboratory of the borehole repository should define:

- Suitability of the selected construction subsite for solidified RW storage;

- Key design and technological decisions for construction of the borehole repository.

If results of these investigations are positive, the underground borehole laboratory may become an experimental commercial RW repository.

Upon the completion of in-situ experiments, we will compile information about the design and construction materials concerning building and operation of the laboratory, and compile data obtained from detailed geologic and hydrogeological operations and scientific research in the underground laboratory,. This information serves as the basis for estimates of safety and risk of $\mathrm{RW}$ repository construction on the selected subsite. Then state experts will examine the materials of the rock mass subsite investigations in order to confirm its suitability for RW emplacement. If results of the examination are positive, the TEO for construction of an RW repository of the borehole type will be developed.

\subsection{Development of the TEO for the RW Borehole-type Repository}

The Technical and Economic Justification for the project is based on the results of the engineering surveys executed for construction and operation of the underground laboratory, and, also, on the results of comprehensive scientific research under natural conditions.

Surveys will also be conducted to support design decisions for the RW repository and activities on environmental protection.

\subsubsection{Engineering surveys}

Engineering surveys for the TEO address similar problems and are implemented by the same methods as the surveys described in item 2.5. However, the level of detail is higher and they are presented on a scale of 1:5000 to 1:2000. They include:

- Engineering-geological survey;

- Surface geophysical studies (seismic prospecting, electroprospecting);

- Geodetic work;

- Radiation survey of individual parts of the construction subsite;

- Gamma-ray survey of surface facility construction areas and technological boreholes; 
- Boreholes of 800-1200 m and 150-300 m depth drilled to detail geologic and hydrogeological rock mass conditions within the boundaries of the repository and its buffer zone. The complex of investigations in boreholes is similar to that described in item 3.4.1. In addition, seismic-ray examination of the rock mass will be made.

- Additional engineering-ecological surveys;

- Investigations on geodynamic polygons.

These surveys will produce the data requirements listed in item 2.5.1.

\subsubsection{Scientific research}

Scientific research for TEO development is similar to the research described in item 2.5.2:

- Experiments conducted in the underground laboratory and the results processed;

- Engineering-geologic and migration models worked out in detail including data from borehole drilling;

- Forecasts of variations of natural surroundings for preset periods of time are developed.;

- Data for the substantiated design and construction decisions are prepared.

\subsubsection{Development of TEO design and construction decisions}

Design and construction decisions for RW repositories are grounded to considerable degree on the results of investigations in the underground laboratory and subsequent engineering surveys. They include:

- Detailed studies of layout of surface facilities complex;

- Procedure for RW treatment from the moment of delivery up to loading into technological boreholes;

- Engineering equipment of operation processes;

- Measures of radiation safety during work at areas contaminated with radionuclides;

- Procedure for waste package emplacement into a borehole and its permanent closure;

- Preparation of the scheme for the arrangement of technological boreholes, and substantiation of it;

- Assessment of impact of RW on the environment and activities for environmental protection.

Based on the completed surveys, and, also, on the results of scientific research in the underground laboratory, the TEO for the RW repository and a justification of the safety of the selected subsite will be prepared.

Then the TEO documentation will be considered by the state supervising entities, who will judge the results and the decisions. If their conclusion is positive, the design is approved, and the decision on RW repository construction is final.

The proposed labor effort for the TEO stage amounts to 491 man years (Table 5). 


\subsection{Development of Working Documentation for RW Borehole Repository}

\subsubsection{Engineering surveys}

The purpose of the engineering surveys in development of the working documentation for the RW repository are similar to those stated in item 2.6.1. The surveys are carried out on a scale of 1:2000 to 1:1000. They include:

- Engineering-geological survey for building surface facilities;

- Geodetic studies for compiling the master plan for surface and underground structures;

- Surface geophysical studies (seismic prospecting, electroprospecting) at individual construction areas;

- Boreholes drilled with core sampling and the full complex of geologic-geophysical and hydrogeological studies. The depth of a borehole is defined by its position in a rock mass. Six or more boreholes $1200-1500 \mathrm{~m}$ deep may be drilled;

- Geodynamic studies on special polygons;

- Hydrometeorological observations;

- Laboratory studies.

The scope and type of these investigations will be determined by the results of previously completed design and exploration work.

\subsubsection{Scientific support}

Scientific studies at a given stage of design are stated in detail in item 2.6.2.

\subsubsection{Development of the Working Documentation}

Design and construction work is focused on detailing and specifying design decisions adopted at the TEO stage (item 3.6.3). The Working Documentation (WD) covers the scope of significant problems (item 2.6.3). In the WD, we elaborate the design documentation for surface facilities; establish the structure of technological boreholes, including their location, depth, and sequence of operations; and develop measures for environmental protection and remediation.

Total labor efforts at this stage are estimated at 574 man years (Table 5).

\subsection{Construction, Operation, and Closure of RW Borehole Repository}

\subsubsection{Construction of RW repository}

The work includes construction of surface buildings for various applications, driving, and layout of technological boreholes-disposals, including:

- Laying and arrangement of access roads, service lines, and surface production areas, construction of office and industrial buildings and structures;

- Creation of geomonitoring system; 
Table 5. Summary of labor effort for design and survey work for the RW borehole repository in the PA "Mayak" buffer zone.

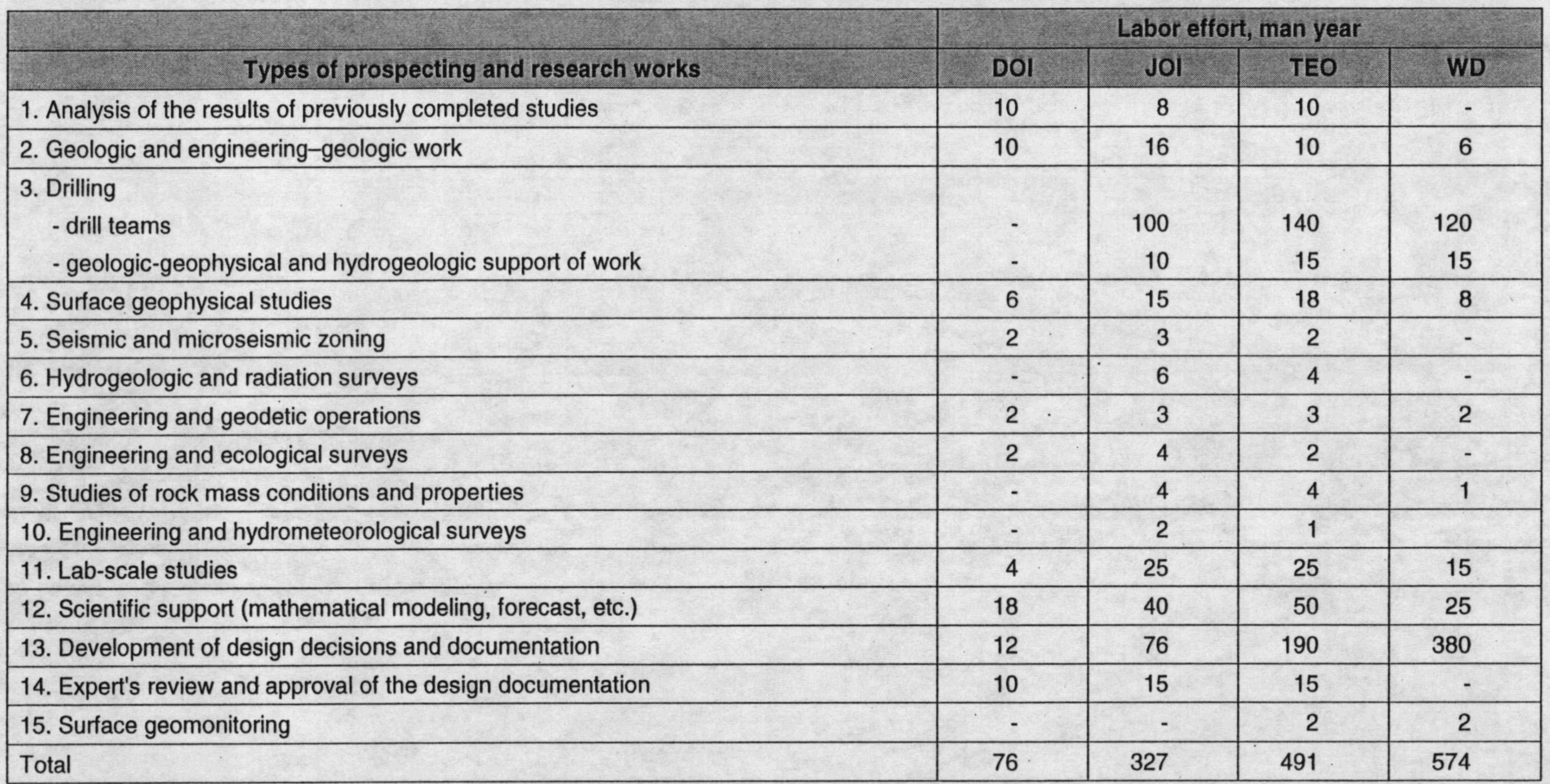

1. Data on labor effort of research and development and design and exploration works are submitted without regard of underground laboratory and will be revised.

2. The given labor effort for prospecting and drilling (items 2-10) is given for analysis of territory of category 1. Territory of PA "Mayak" is referred to category II, besides it is contaminated with radionuclides. In this connection total labor effort for these operations may be increased.

3. Capital costs will be evaluated at JOI stage. 
- Drilling technological boreholes. Before construction of technological boreholes of larger diameter, $900 \mathrm{~mm}$ and more, pilot boreholes can be drilled to study mining and geological conditions for driving. Technological boreholes of smaller diameter and pilot boreholes will serve to carry out the special complex of geologic-geophysical and hydrogeological investigations;

- Technological borehole areas completed, equipment installed for RW loading into boreholes and, access and inside roads are laid.

\section{Engineering surveys and scientific research}

Engineering-geologic surveys performed during construction, operation, and liquidation of the RW borehole repository should acquire any missing data on the state and variations of individual elements of the geologic environment. The surveys will be carried out to increase the reliability and operational suitability of technological boreholes for surface facilities, safety of operations, protection of the environment and future human health.

During drilling, the excavated rock mass sections are examined to see if they conform to the design documentation. Necessary geologic-geophysical and hydrogeological operations will be carried out, and samples of water and rocks taken for laboratory studies. The intervals between technological boreholes will be defined from the results of this examination.

In case of discrepancies between actual engineering-geological conditions and those accepted in the design, design decisions should be revised, and recommendations given to specify the actual layout of the technological boreholes.

Models of the disposal surroundings and the system of waste-engineered barriers for the enclosing rock massif are finalized. Based on these models, the technological decisions associated with RW storage (i.e., interval between technological boreholes, number of waste packages, which can be emplaced in this or that part of the excavated rock mass, volume of packing materials, etc.) are specified.

Investigations of hydrodynamic, hydrochemical, radiochemical, and temperature conditions of the rock mass will be carried out in observation boreholes, and water samples taken for various kinds of analysis.

\subsubsection{Operation of the $\mathrm{RW}$ repository}

Operation of the repository involves multiple activities. The chief activities are listed below:

- Delivery of waste packages in protective casings and containers to borehole areas. Extraction of waste packages and containers, and then loading them into boreholes. When a borehole is partially or completely filled with packing materials (i.e., bentonite clay), concrete seals are made, if necessary.

- Boreholes for waste package emplacement are drilled periodically to enlarge the RW storage volume;

- Geomonitoring of individual elements of the geologic environment includes the studies, described in 3.8.1. 


\subsubsection{Permanent closure of the RW repository}

When borehole local zones are filled up, bentonite is packed into the cavities in the boreholes. When working zones are completely filled, the boreholes are sealed with bentonite.

Data from engineering surveys during RW repository closure are submitted according to item 2.7.3.

Environmental studies are carried out with the help of regime network (surface and underground waters) and on polygons. Rehabilitation of the RW repository site will be carried out after permanent closure of the RW repository. 
Table 6. Preliminary schedule for construction of RW borehole repository in buffer zone of PA "Mayak"

\begin{tabular}{|c|c|c|c|c|c|c|c|c|c|c|c|c|c|c|c|c|c|c|c|c|c|c|c|}
\hline \multirow{2}{*}{$\begin{array}{c}\text { Phase, type and stage } \\
\text { of works }\end{array}$} & \multicolumn{23}{|c|}{ Date of work completion in years from the beginning of the project } \\
\hline & 01 & 02 & 03 & 04 & 05 & 06 & 07 & 08 & 09 & 10 & 11 & 12 & 13 & 14 & 15 & 16 & 17 & 18 & 19 & 20 & 21 & 22 & 23 \\
\hline \multicolumn{24}{|l|}{ 1.Design works } \\
\hline \multicolumn{24}{|l|}{ DOI. } \\
\hline \multicolumn{24}{|l|}{ JOI } \\
\hline \multicolumn{24}{|l|}{ TEO. } \\
\hline Working documents. & & & & & & & & & & & & & & & 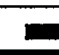 & 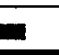 & & & & & & & \\
\hline \multirow{2}{*}{\multicolumn{24}{|c|}{$\begin{array}{l}\text { 2. Engineering and } \\
\text { geologic surveys }\end{array}$}} \\
\hline & & & & & & & & & & & & & & & & & & & & & & & \\
\hline \multicolumn{24}{|l|}{$\begin{array}{l}\text { 3. Underground } \\
\text { laboratory. }\end{array}$} \\
\hline \multicolumn{24}{|l|}{ Draft design. } \\
\hline \multicolumn{24}{|l|}{ Construction } \\
\hline \multicolumn{24}{|l|}{$\begin{array}{l}\text { Scientific research in } \\
\text { rock massif }\end{array}$} \\
\hline \multicolumn{24}{|l|}{$\begin{array}{l}\text { 4. Construction of the } \\
\text { repository. }\end{array}$} \\
\hline \multicolumn{24}{|l|}{$\begin{array}{l}\text { 5. } \mathrm{RW} \text { loading of the } \\
\text { repository }\end{array}$} \\
\hline 6. Geoecological & & & & & & & & & & & & & & & & & & & & & & & \\
\hline monitoring. & & & & & & & & & & & & & & & & & & & & & & & \\
\hline
\end{tabular}

